\title{
Coumarin-Annulated Ferrocenyl 1,3-Oxazine Derivatives Possessing In Vitro Antimalarial and Antitrypanosomal Potency
}

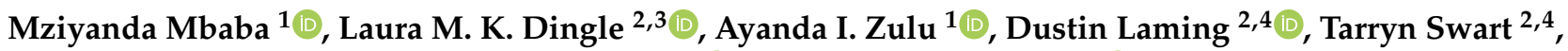 \\ Jo-Anne de la Mare ${ }^{2,3,4}$, Heinrich C. Hoppe ${ }^{2,4}\left(\mathbb{D}\right.$, Adrienne L. Edkins ${ }^{2,3,4}$ (D) and Setshaba D. Khanye ${ }^{1,4,5, *(\mathbb{D})}$ \\ 1 Department of Chemistry, Faculty of Science, Rhodes University, Makhanda 6140, South Africa; \\ mziyanda.mbaba@uct.ac.za (M.M.); azulu50@gmail.com (A.I.Z.) \\ 2 Department of Biochemistry and Microbiology, Faculty of Science, Rhodes University, \\ Makhanda 6140, South Africa; lauradingle25@hotmail.co.uk (L.M.K.D.); dustinlaming89@gmail.com (D.L.); \\ g10s2905@campus.ru.ac.za (T.S.); j.delamare@ru.ac.za (J.-A.d.1.M.); h.hoppe@ru.ac.za (H.C.H.); \\ a.edkins@ru.ac.za (A.L.E.) \\ 3 Biomedical Biotechnology Research Unit, Rhodes University, Makhanda 6140, South Africa \\ 4 Centre for Chemico- and Biomedicinal Research, Rhodes University, Makhanda 6140, South Africa \\ 5 Division of Pharmaceutical Chemistry, Faculty of Pharmacy, Rhodes University, Makhanda 6140, South Africa \\ * Correspondence: s.khanye@ru.ac.za; Tel.: +27-46-603-8397
}

Citation: Mbaba, M.; Dingle, L.M.K.; Zulu, A.I.; Laming, D.; Swart, T.; de la Mare, J.-A.; Hoppe, H.C.; Edkins, A.L.; Khanye, S.D. CoumarinAnnulated Ferrocenyl 1,3-Oxazine Derivatives Possessing In Vitro Antimalarial and Antitrypanosomal Potency. Molecules 2021, 26, 1333. https: / / doi.org/10.3390/ molecules26051333

Academic Editors:

Evamarie Hey-Hawkins,

Santiago Gómez-Ruiz and Goran Kaluđerović

Received: 5 February 2021

Accepted: 25 February 2021

Published: 2 March 2021

Publisher's Note: MDPI stays neutral with regard to jurisdictional claims in published maps and institutional affiliations.

Copyright: (c) 2021 by the authors. Licensee MDPI, Basel, Switzerland. This article is an open access article distributed under the terms and conditions of the Creative Commons Attribution (CC BY) license (https:/ / creativecommons.org/licenses/by/ $4.0 /)$.

\begin{abstract}
A tailored series of coumarin-based ferrocenyl 1,3-oxazine hybrid compounds was synthesized and investigated for potential antiparasitic activity, drawing inspiration from the established biological efficacy of the constituent chemical motifs. The structural identity of the synthesized compounds was confirmed by common spectroscopic techniques: NMR, HRMS and IR. Biological evaluation studies reveal that the compounds exhibit higher in vitro antiparasitic potency against the chemosensitive malarial strain (3D7 P. falciparum) over the investigated trypanosomiasis causal agent (T. $b$. brucei 427 ) with mostly single digit micromolar $\mathrm{IC}_{50}$ values. When read in tandem with the biological performance of previously reported structurally similar non-coumarin, phenyl derivatives (i.e., ferrocenyl 1,3-benzoxazines and $\alpha$-aminocresols), structure-activity relationship analyses suggest that the presence of the coumarin nucleus is tolerated for biological activity though this may lead to reduced efficacy. Preliminary mechanistic studies with the most promising compound (11b) support hemozoin inhibition and DNA interaction as likely mechanistic modalities by which this class of compounds may act to produce plasmocidal and antitrypanosomal effects.
\end{abstract}

Keywords: organometallic; bioorganometallic; ferrocene; coumarin; oxazine; malaria; trypanosomiasis; cancer; Plasmodium falciparum; Trypanosoma brucei; mode of action

\section{Introduction}

Malaria and trypanosomiasis are protozoal infections that are endemic in tropical regions. Both diseases are vector-borne and are transmitted through the bite of infected female Anopheles mosquitos and tsetse flies, respectively. Of the five known protozoal species of the genus Plasmodium (i.e., P. falciparum, P. vivax, P. knowlesi, P. ovale and P. malariae), P. falciparum and $P$. vivax are responsible for the most cases of malaria, with the former accounting for more than 99\% of infections in the African continent in 2018 alone, according to the World Health Organisation [1,2]. Infection of the human host with protozoal Trypanosoma species causes human African trypanosomiasis (also known as sleeping sickness) [3]. Although these diseases are preventable and curable, courtesy of cutting-edge medical technologies of the modern day and the concerted efforts by both the public and private sector, they still pose a great burden to the healthcare sector in developing economies and threaten many lives. Particularly, initiatives such as the Medicines for Malaria Venture (MMV) and Drugs for Neglected Diseases Initiative (DNDi) are among the leading programmes of the past decades that spear-headed drug discovery innovation directed towards the 
cause of eradicating tropical diseases, including malaria and trypanosomiasis [4,5]. Despite these efforts, the causal agents of these diseases are increasingly becoming resistant to current clinical drugs employed for their treatment. For instance, emergence of P. falciparum strains that are resistant to the highly efficacious artemisinin-combination therapies (ACTs), introduced by $\mathrm{WHO}$ as a failsafe for malaria resistance [6], have already been recorded [7]. Hence, research towards the design and biological assessment of novel therapeutic agents that can elude or impede the development of clinical resistance by pathogens is an active field in contemporary drug discovery.

Medicinal and bioorganometallic chemists are turning to the use of nonconventional organometallic complexes, employing contemporary drug discovery strategies that incorporate mechanistically distinct pharmacophores, as potential alternative medicinal agents with unique modes of action that can possibly overcome the scourge of clinical resistance [8-10]. Ferrocene is the prime example in the application of organometallic complexes in medicinal chemistry due to its attractive physicochemical attributes such as high lipophilicity, reversible redox character and ability to generate membrane disruptive reactive oxygen species (ROS) in biological media [11,12]. The incorporation of ferrocene into the known antimalarial drug scaffold, chloroquine (1, CQ), and the framework of an anticancer agent, tamoxifen (2), respectively, yielded an ingenious antimalarial clinical candidate, ferroquine (3, FQ), and a cohort of promising pre-clinical anticancer leads, ferrocifens (4-8) (Figure 1) [13-16]. These organometallic compounds display superior biological performance to their organic parent drugs on the respective diseases and possess distinct, complementary mechanisms of action, which are attributed to the presence of ferrocene. Consequently, the success of ferroquine and ferrocifens have inspired researchers to introduce ferrocene to other bioactive organic motifs, like quinoline [17-20], indole [21-23], benzimidazole [24,25] and oxanes [26-28], to modulate their therapeutic efficacy for a myriad of biological applications.<smiles>CCN(CC)CCCC(C)Nc1ccnc2cc(Cl)ccc12</smiles>

1, Chloroquine $(\mathrm{CQ})$

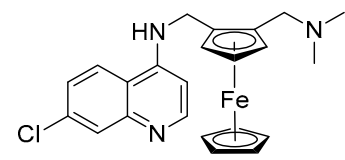

3, Ferroquine (FQ)

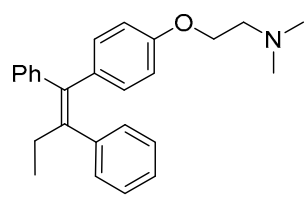

2, Tamoxifen

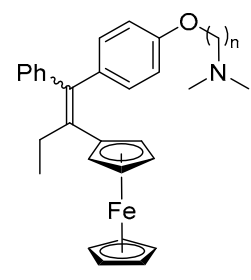

4-8: $n=2-6$

Figure 1. Chemical structures of chloroquine (1), tamoxifen (2) and their ferrocenyl derivatives ferroquine (3) and ferrocifens (4-8).

Coumarins are prominent heterocyclic compounds in medicinal chemistry and show a wide spectrum of biological activities including anticancer [29,30], antimalarial [31,32], antitrypanosomal [33,34], antileishmanial [35,36] and antitubercular effects [37,38]. Previously, we demonstrated that introducing ferrocene into the naturally occurring coumarinbased antibiotic, novobiocin, by replacing the benzamide side chain enhanced the in vitro antiproliferative effects of the resulting ferrocenyl derivatives, i.e., ferrobiocins, against triple-negative human breast cancer cells (HCC38 and MB-DA-231) and endowed the new compounds with antiplasmodial activity against chemosensitive 3D7 P. falciparum trophozoites in vitro $[39,40]$. Furthermore, the research groups of Yan and Zhang synthesized and evaluated the in vitro anticancer activity of ferrocenyl coumarins against several 
cancer cell lines with activities in the low and mid-micromolar range [41,42]. Apart from these limited accounts, there are no other reports on the biological activity of ferrocenyl coumarin derivatives as far as we know. We have also recently showed that ferrocenyl 1,3-benzoxazines, commonly utilised as precursors in the synthesis of electrochemically active polymers [43-45], could be repurposed as potential medicinal agents against malaria and trypanosomiasis as well as breast cancer [46]. The 1,3-oxazine moiety was found to play a crucial role in the biological activity of these compounds [46,47]. Presented with the prolific biological profile of coumarins and the encouraging results obtained from conjugating coumarin and ferrocene and the significant pharmacological role of the oxazine unit in ferrocenyl 1,3-benzoxazines, we envisaged combining these structural units, i.e., coumarin, oxazine and ferrocene, to explore the antiplasmodial and antitrypanosomal potential of the resulting hybrid compounds against the chloroquine-sensitive (CQS) 3D7 P. falciparum strain and T. brucei brucei trypomastigotes. Preliminary mechanistic studies using a representative compound as a tool suggest DNA interaction and hemozoin inhibition as possible modes of action by which the investigated conjugates may elicit biological activity.

\section{Results}

\subsection{Chemistry}

Given our promising findings with previously reported ferrocenyl 1,3-benzoxazines [46], as well as their non-cyclic aminocresol counterparts [47], we envisioned expanding the benzene ring in order to gain better insights into the structure-activity relationship profile of this class of compounds by replacing this unit with a privileged coumarin scaffold. Thus, the target compounds were designed to incorporate all three desired structural units, i.e., coumarin, oxazine and ferrocene, as illustrated in Figure 2. First, a plain ferrocenyl 1,3oxazine unit bearing a $\mathrm{O}-\mathrm{CH}_{2}-\mathrm{N}$ bridge was appended to the benzene ring of the coumarin nucleus (A) (Figure 2). Second, considering the postulated pharmacophoric importance of the oxazine $\mathrm{O}-\mathrm{CH}_{2}-\mathrm{N}$ connectivity $[48,49]$, we introduced a carbonyl group to produce less basic carbamate analogues, i.e., coumarin-1,3-oxazin-2-ones (B), containing a O-CO-N oxazine linkage annulated to the prone unit (Figure 2). In our literature search we noted that there are numerous examples of benzene annulated coumarin-oxazines in the literature, however, we could only find one account of the pyrone-amended counterparts [50]. In light of this, and as a secondary objective of the current study, we directed our efforts towards pursing the lesser explored pyrone-annulated congeners (B) of these compounds for biological assessment. Lastly, we varied the basic ferrocenyl methyl(dimethylamine) motif $\left(\mathrm{R}=\mathrm{CH}_{2} \mathrm{NMe}_{2}\right)$ known to enhance biological activity, e.g., in ferroquine [13], by removing it to produce representative compounds lacking this moiety $(\mathrm{R}=\mathrm{H})$ in order to probe its pharmacological significance.

Parent ferrocenyl 1,3-benzoxazines

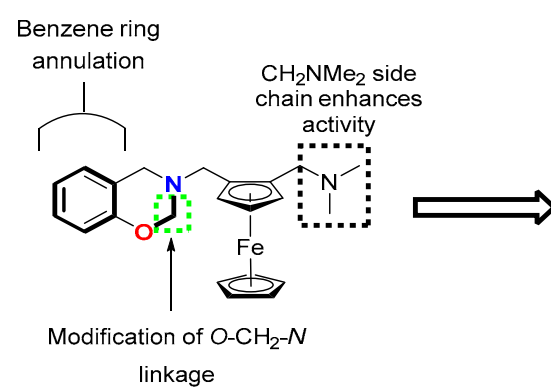

Cyclic and noncyclic

coumarin-oxazine derivatives

investigated in the current study

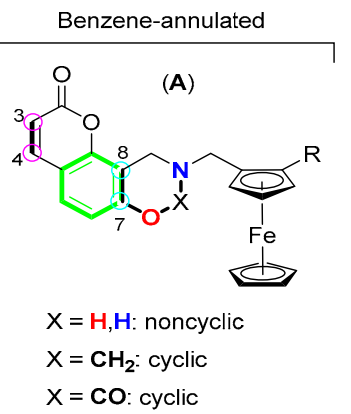

Pyrone-annulated

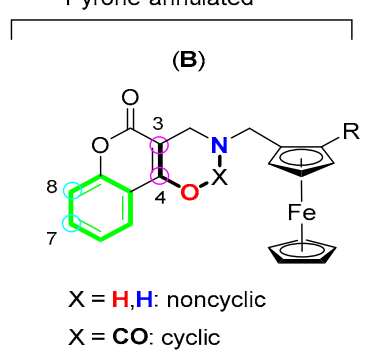

Figure 2. Design of ferrocenyl coumarin-oxazine hybrid compounds pursued in this study. 
Synthesis of the target compounds was achieved by reductive amination of formyl hydroxycoumarins 9 and 14a-c with ferrocene methylamines 10a,b, prepared according to literature methods $[13,51-54]$, that was affected by sodium borohydride as the reducing agent in yields ranging between 66 and $86 \%$ (Scheme 1) [55]. Benzene-annulated hybrid compound 13 was readily obtained by cyclisation of the corresponding aminocoumarin-7-ol $\mathbf{1 1 b}$ under reflux with paraformaldehyde [46]. However, pyrone-annulated aminocoumarin4-ols (15a-d) did not cyclize under these conditions. The use of a previously reported SDS-mediated cyclisation procedure for pyrone-annulated coumarin-1,3-oxazines proved unsuccessful in furnishing the desired products 17a-d, either [50]. The failure of the alcohols to cyclize could be a result of the non-aromaticity of the pyrone ring and effects of keto-enol tautomerism [56], both of which are not conducive for electrophilic aromatic substitution via which the reaction proceeds [57]. Cyclisation of these substrates (15a-d) was thus achieved by reaction with $1,1^{\prime}$-carbonyldiimidazole (CDI) to yield the corresponding less basic benzene- and pyrone-annulated coumarin-oxazin-2-ones (12a, $\mathbf{b}$ and $\mathbf{1 6} \mathbf{a}-\mathbf{d}$, respectively) [58]. Lastly, we included a hybrid compound (19) containing a fused, two-ring sesamyl unit featuring a benzodioxole motif in lieu of the coumarin nucleus for comparison purposes. This was synthesized as previously described for compound $\mathbf{1 3}$ above employing two equivalents of paraformaldehyde instead of one [46]. For the discussion of biological results, we also included structurally related naphthoxazines $\mathbf{2 0 a}, \mathbf{b}$, which we reported elsewhere [46], as part of the SAR elucidation campaign to gain a better understanding of the pharmacological effects of expanding the benzene ring.

The structural identity of all the compounds was confirmed by common spectroscopic techniques: nuclear magnetic resonance $\left({ }^{1} \mathrm{H}\right.$ and ${ }^{13} \mathrm{C}$ NMR $)$ and high-resolution mass spectrometry (HRMS). The absence of the aldehyde signal and appearance of new ferrocenyl and methylene peaks in their distinctive regions at $\delta 4.51-4.01 \mathrm{ppm}$ and $\delta 4.99-3.02 \mathrm{ppm}$, respectively, verified successful amination of formyl hydroxycoumarins ( 9 and $\mathbf{1 4 a}-\mathbf{d}$ ) in the ${ }^{1} \mathrm{H}$ NMR spectra of products 11a,b and 15a-d. This was corroborated by ${ }^{13} \mathrm{C}$ NMR data. Assignment of the proton signals was achieved by multiplet analysis of the ${ }^{1} \mathrm{H}$ NMR signals as well as 2D NMR techniques: COSY, HSQC and HMBC (Supporting Information). The ${ }^{13} \mathrm{C}$ NMR data of coumarin-oxazin-2-ones (12a,b and 16a-d) were invaluable in the confirmation of successful cyclization of aminohydroxycoumarin substrates $(\mathbf{1 1} \mathbf{a}, \mathbf{b}$ and 15a-d), which revealed the new CO signals around $\delta 147.0 \mathrm{ppm}$, characteristic of the carbamate unit. For the plain cyclic coumarin- and sesamyl-oxazines (13 and 19), the distinctive oxazine methylene protons resonated at $\delta 4.96-4.78 \mathrm{ppm}\left(\mathrm{O}-\mathrm{CH}_{2}-\mathrm{N}\right)$ and $\delta 4.06-4.02 \mathrm{ppm}$ (aryl- $\mathrm{CH}_{2}-\mathrm{N}$ ) as previously observed in the literature [46]. 
<smiles>O=Cc1c(O)ccc2ccc(=O)oc12</smiles>

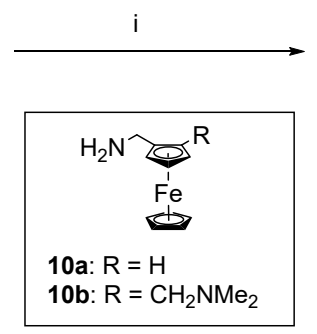<smiles>[R]c1ccc2oc(=O)c(C=O)c(O)c2c1</smiles>

14a: $R=H$

$14 \mathrm{~b}: \mathrm{R}=\mathrm{Cl}$

14c: $R=F$
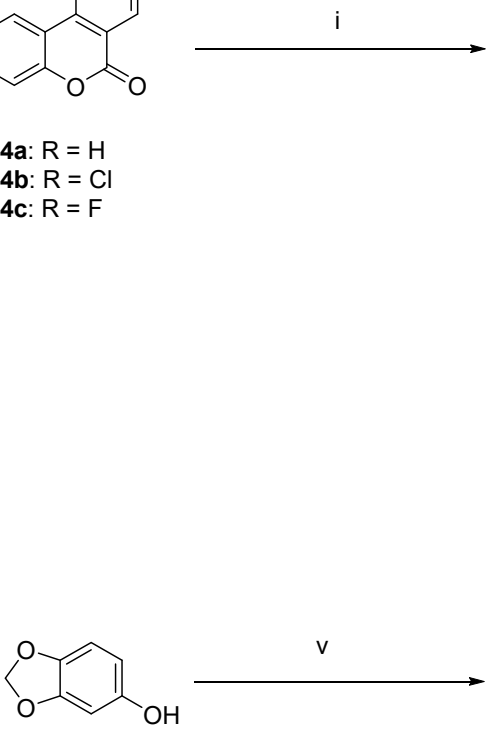

18

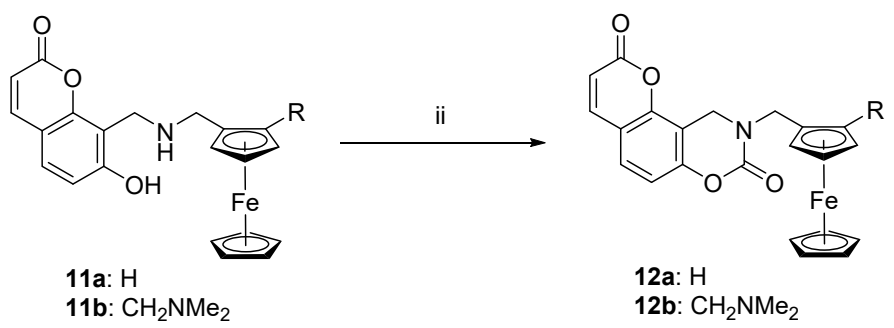<smiles>CN(C)Cc1cc(CN2COc3ccc4ccc(=O)oc4c3C2)cc(Oc2ccccc2)c1</smiles><smiles>[Y16]c1ccc(Oc2ccccc2)c(CN2Cc3c(c4cc([R])ccc4oc3=O)OC2=O)c1</smiles>

$15 a-d$

16a-d

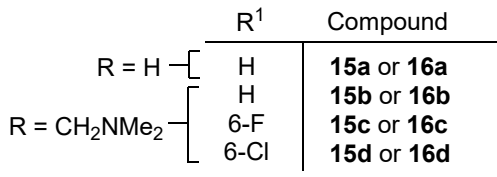

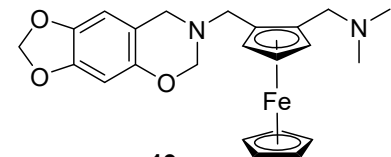

19

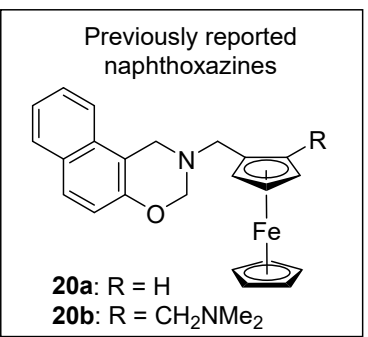

Scheme 1. Synthesis of noncyclic and cyclic ferrocenyl coumarin-oxazine derivatives. Reaction conditions: (i) ferrocenyl amine (10a or 10b, 1.0 eq.), EtOH, reflux, 5-6 h followed by $\mathrm{NaBH}_{4}$ (2.0 eq.), r.t. to reflux, 15-30 min; (ii) CDI (1.0 eq.), DCM, r.t., $1-2 \mathrm{~h}$; (iii) paraformaldehyde (1.0 eq.), $\mathrm{CHCl}_{3}$, reflux, $10 \mathrm{~h}$; (iv) paraformaldehyde (2.0 eq.), $\mathrm{FeCl}_{3}(10 \mathrm{~mol} \%)$, aq. SDS (10 mol\%), r.t., $12 \mathrm{~h}$; (v) paraformaldehyde (2.0 eq.), $\mathrm{CHCl}_{3}$, reflux, $10 \mathrm{~h}$.

\subsection{Biological Evaluation}

The in vitro antimalarial and trypanocidal activities of the target compounds was realised on the blood-stage CQS 3D7 P. falciparum trophozoites and nagana T. b. brucei 427 trypomastigotes, respectively. The biological evaluation results are presented in Table 1. Excluding 11b, all the compounds were also assessed for antiproliferative effects against the HCC70 triple-negative breast cancer cell line. However, none of the tested coumarinand sesamyl-oxazine derivatives were effective at inhibiting the growth of the evaluated cells at the tested concentration ( $25 \mu \mathrm{M}$ single point screening, data not shown). 
Table 1. Antiplasmodial and antitrypanosomal activities of target compounds against 3D7 P. falciparum trophozoites and nagana T. b. brucei 427 trypomastigotes.

\begin{tabular}{|c|c|c|}
\hline \multirow{2}{*}{ Compound } & \multicolumn{2}{|c|}{$\mathrm{IC}_{50}(\mu \mathrm{M})$} \\
\hline & 3D7 P. falciparum & T. b. brucei 427 \\
\hline 11a & 9.1 & n.a. ${ }^{a}$ \\
\hline $11 b$ & 1.7 & 9.4 \\
\hline $12 a$ & n.a. & n.a. \\
\hline $12 b$ & 7.3 & n.a. \\
\hline 13 & 1.0 & n.d. ${ }^{b}$ \\
\hline $15 a$ & n.a. & n.a. \\
\hline $15 b$ & n.a. & n.a. \\
\hline $15 c$ & 8.76 & 19.6 \\
\hline $15 d$ & 5.7 & 5.0 \\
\hline $16 a$ & 13.2 & n.a. \\
\hline $16 b$ & n.a. & n.a. \\
\hline $16 \mathrm{c}$ & 12.55 & n.a. \\
\hline $16 d$ & n.a. & n.d. \\
\hline 19 & 4.78 & n.d. \\
\hline $20 a^{c}$ & 3.49 & n.a. \\
\hline $20 b^{c}$ & 4.12 & 0.87 \\
\hline CQ & 0.03 & - \\
\hline Pentamidine & - & 0.014 \\
\hline
\end{tabular}

a not determined; ${ }^{b}$ not determined; ${ }^{c}$ biological data was adapted from a previously reported study [46].

The investigated compounds were more selective for the plasmodial parasites over the trypomastigotes, with at least a 2-fold increase in activity. With the exception of 16a, acyclic derivatives (e.g., 11a,b and 15c,d) exerted better potencies than their cyclic coumarinoxazin-2-one variants (e.g., 12a, $\mathbf{b}$ and $\mathbf{1 6 c}$,d) against both pathogens, with compound $\mathbf{1 1 b}$ commanding the highest activities in the $\alpha$-aminohydroxycoumarin series: $\mathrm{IC}_{50}=1.7 \mu \mathrm{M}$ (3D7) and $9.4 \mu \mathrm{M}$ (427). This could be attributed to the effect of the intramolecular hydrogen bond between the amine $(\mathrm{NH})$ and hydroxyl $(\mathrm{OH})$ groups of the aminohydroxycoumarins, which has been postulated to be pivotal for biological activity in similar ferrocenyl $\alpha$ aminocresols and other antiparasitic agents reported in the literature $[47,59]$. The plain coumarin-oxazine $\mathbf{1 3}$ was the most active in the whole series against the P. falciparum strain with an $\mathrm{IC}_{50}$ value of $1.0 \mu \mathrm{M}$, while its sesamyl congener 19 displayed activity of $4.78 \mu \mathrm{M}$. Naphthoxazines 20a,b showed comparable antiplasmodial activities $\left(\mathrm{IC}_{50}=3.39 \mu \mathrm{M}(\mathbf{2 0 a})\right.$ and $4.12 \mu \mathrm{M}(\mathbf{2 0 b}))$ to sesamyl-oxazine 19 , and were more active than the pyroneannulated coumarins (15a-d and 16a-d) [46]. Preliminary screening of the compounds for general toxicity effects and selectivity for parasitic cells was assessed on the mammalian cervical cancer HeLa cell line and effected at least $60 \%$ viability of these mammalian cells (see Figure S1, Supporting Information). This suggests a higher selectivity profile of the compounds for the parasitic pathogens over mammalian cells at the tested concentration.

SAR analysis shows that modification of the coumarin nucleus on the benzene ring, either by the introduction of an $\alpha$-aminocresol moiety $(\mathbf{1 1} \mathbf{a}, \mathbf{b})$ or annulation with an oxazin2-one unit (12a,b), is more favourable for activity than annulation on the pyrone unit (15a-d and 16a-d) (Table 1). This is further attested by the activity of the benzene-annulated sesamyl-oxazine 19 and naphthoxazines $20 a, b$, which were many times more potent than the pyrone-modified coumarin derivatives $(15 \mathbf{a}-\mathbf{d}$ and $\mathbf{1 6} \mathbf{a}-\mathbf{b})$. Since the pyrone unit is non-aromatic, the takeaway from this is that the phenolic oxygen atom contained in the benzene-annulated analogues is crucial for biological activity. Concerning the effect of the oxazine rings, cyclisation with the $\mathrm{O}-\mathrm{CH}_{2}-\mathrm{N}$ linkage (13) is more desirable for activity compared to the less basic $\mathrm{O}-\mathrm{CO}-\mathrm{N}$ connection $(\mathbf{1 2} \mathbf{a}, \mathbf{b})$. This emphasizes the pharmacological significance of the $\mathrm{O}-\mathrm{CH}_{2}-\mathrm{N}$ linkage as previously observed for parent ferrocenyl benzoxazines [46]. Substitution at coumarin C-6 with fluorine $\left(\mathbf{1 5 c}, \mathrm{IC}_{50}=8.76 \mu \mathrm{M}\right.$ [3D7] and $19.6 \mu \mathrm{M}$ [427]) exerted slightly inferior activity compared to chlorine $\left(\mathbf{1 5 d}, \mathrm{IC}_{50}=5.7 \mu \mathrm{M}\right.$ 
[3D7] and $5.0 \mu \mathrm{M}$ [427]) for acyclic derivatives (15a-d), while this effect was reversed for the cyclic analogues (16a-d, $\mathrm{IC}_{50}=12.55 \mu \mathrm{M}$ (3D7) [16c] vs. n.a. (3D7) [16d]) (Table 1). On the other hand, the presence of the hydrogen atom was detrimental for activity as all compounds with this group were inactive against both parasites. Regarding the modification of the ferrocene unit, compounds containing the ferrocenyl $\mathrm{CH}_{2} \mathrm{NMe}_{2}$ motif on the top cyclopentadiene ring $(\mathrm{Cp})$ were generally more effective than their congeners lacking this unit, signifying its pharmacological importance. In view of the superior antiplasmodial and antitrypanosomal activities of previously reported parental ferrocenyl 1,3-benzoxazines and $\alpha$-aminocresols (noncyclic analogues) that were active in low and sub-micromolar range [46,47], the moderate biological performance of the ring-expanded coumarin-oxazines investigated in the current study suggests that replacing the benzene ring of the parent scaffold with a coumarin nucleus leads to reduced antiparasitic activity. Nevertheless, benzene-annulated coumarin-oxazine derivatives $\mathbf{1 1 b}$ and $\mathbf{1 3}$ display similar potencies to their previously reported benzoxazine and $\alpha$-aminocresol counterparts in the same order of magnitude $[46,47]$, indicating that the coumarin nucleus is reasonably tolerated for activity when annulated on the benzene unit. The structural bulk of coumarin could also impart other beneficial medicinal qualities like high lipophilicity and better interaction with pathological biomolecules like nucleic acids (DNA) and proteins.

\subsection{Preliminary Mechanistic Studies}

Using coumarin derivative $\mathbf{1 1 b}$ as a tool compound, we endeavoured to undertake introductory mechanistic investigation of the the presented compounds, targeting hemozoin inhibition (a mainstay antimalarial target) and DNA binding affinity. This was achieved by employing the detergent-mediated $\beta$-hematin (synthetic hemozoin) binding assay reported by Ncokazi and Egan for assessing hemozoin inhibitory effects of antimalarial compounds $[60,61]$, and spectrophotometric DNA titration techniques (UV-Vis and fluorescence) adapted from the literature [62-64].

The $\beta$-hematin inhibition was conducted as previously reported, employing varying concentrations of compound $\mathbf{1 1 b}$ in DMSO alongside CQ as a control drug that was incubated with a fixed amount of $\beta$-hematin solution followed by the addition of NP-40 detergent to induce polymerisation [47]. The ability of compounds to inhibit hemozoin formation was monitored by measuring the absorbance of the unpolymerized haem complex at $405 \mathrm{~nm}$ and quantifying this response in terms of $\mathrm{IC}_{50}$ value $(50 \%$ inhibitory concentration). The tool compound $\mathbf{1 1 b}$ exhibited hemozoin inhibitory concentration of $337.5 \pm 1.15 \mu \mathrm{M}$ that was similar to that of $\mathrm{CQ}\left(\mathrm{IC}_{50}=329.6 \pm 1.04 \mu \mathrm{M}\right)$ (Figure 3). Considering that these values are comparable, although compound $\mathbf{1 1} \mathbf{b}$ was significantly less potent than CQ against the 3D7 P. falciparum strain (Table 1), these results suggest that 11b does not necessarily exert its plasmocidal activity by solely targeting hemozoin formation as the control drug. Effects such as cell and membrane penetrating ability of compound $\mathbf{1 1 b}$ could be another reason to explain the discrepancies between its observed hemozoin inhibitory potential and antiplasmodial activity. 


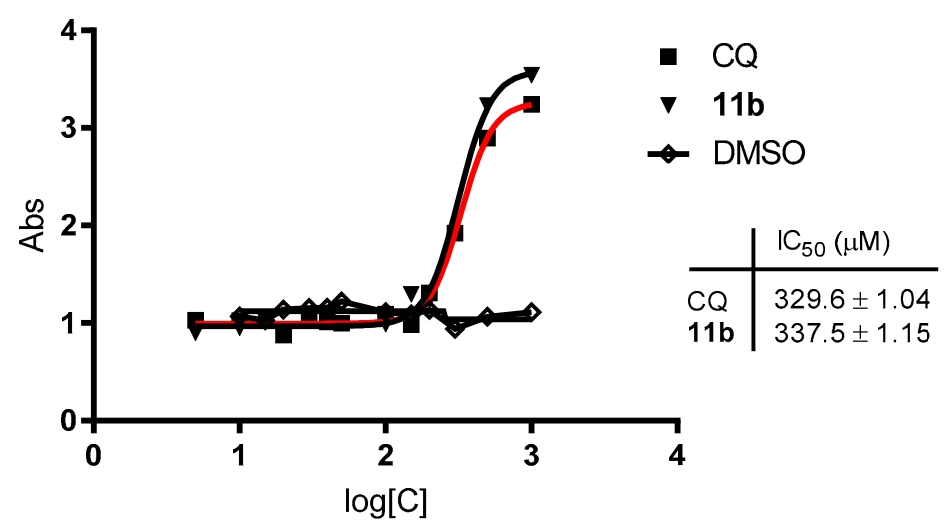

Figure 3. Hemozoin inhibition assay results of compound 11b and CQ from the $\beta$-hematin binding assay. The margin of error is estimated in terms of the standard error $( \pm \mathrm{SE})$.

Next, compound $\mathbf{1 1 b}$ was investigated for DNA binding affinity on mammalian calf thymus DNA employing UV-Vis DNA titration experiments. A constant amount of DNA was titrated with varying concentrations of compound $\mathbf{1 1} \mathbf{b}$ and the absorbance measured at $260 \mathrm{~nm}$, the maximal absorption wavelength of DNA, after an incubation period of $15 \mathrm{~min}$ at ambient temperature $[63,64]$. The interaction of the compound with DNA was confirmed by the dose-dependent hyperchromic shift of the DNA maximal absorption band accompanied by a slight hypsochromic (blue) shift of this band by approximately $4 \mathrm{~nm}$ (Figure 4A), suggesting external binding interactions via noncovalent associations [62-64]. The obtained data was fitted into the reciprocal guest-host equation (Equation (1)) to quantify the binding affinity of compound $\mathbf{1 1 b}$ for DNA in terms of the binding constant $\left(K_{b}\right)$ (Figure $4 B$ ).

$$
\frac{1}{A_{c}-A_{0}}=\frac{1}{K_{b}\left(A_{\infty}-A_{0}\right)} \times \frac{1}{[C]}+\frac{1}{A_{\infty}-A_{0}}
$$

where $A_{c}$ and $A_{0}$ are the absorbance values of the DNA-incubated sample with different compound concentrations and unbound DNA sample at $260 \mathrm{~nm}$, respectively, and $A_{\infty}$ is the hypothetical DNA-compound complex. The $\mathrm{K}_{\mathrm{b}}$ was determined as the ratio of the $y$-intercept to the slope of the equation generated by linear regression analysis of the plot of $1 /\left(A_{c}-A_{0}\right)$ versus $1 /[C]$ (Figure $\left.4 \mathrm{~B}\right)$. From the generated reciprocal guest-host linear equation $(y=131.9 x+0.364)$, a $\mathrm{K}_{\mathrm{b}}$ of $2.77 \times 10^{3} \mathrm{M}^{-1}$ was obtained indicating moderate DNA binding affinity. This binding constant is comparative to the ones observed for the parental ferrocenyl 1,3-benzoxazines and aminocresols in the same order of magnitude [46,47,65].

Compound 11b was further investigated for its mode of DNA binding employing a known DNA intercalator, i.e., methylene blue (MB) [66], and DNA minor groove binder, i.e., Hoechst $33342[67,68]$, for either DNA intercalation or DNA minor groove binding, respectively, using previously reported methods (Figure 4C,D) [46,47]. Compound 11b was unable to amplify fluorescence of the DNA-methylene blue sample (DNA-MB) at both tested concentrations (50 and $100 \mu \mathrm{M}$ ) (Figure $4 \mathrm{C}$ ), which suggests its inability to displace DNA-bound (intercalated) methylene blue molecules from the DNA-MB complex since fluorescence of free $\mathrm{MB}$ molecules is what is monitored in the experiment, thus eliminating it as a DNA intercalator. However, in the assay for competitive minor groove binding with Hoechst 33342, the tool compound (11b) attenuated the intense, maximal fluorescence of the DNA-Hoechst complex at $425-525 \mathrm{~nm}$ by 37 and $50 \%$, accompanied by blue shifts of 30 and $35 \mathrm{~nm}$, for 50 and $100 \mu \mathrm{M}$ tested concentrations, respectively (Figure $4 \mathrm{D}$ ). In view of the fact that intense fluorescence only forms when DNA is bound by the Hoechst dye molecules in the minor groove $[67,68]$, the interpretation of these experimental findings is that $\mathbf{1 1 b}$ competes with the dye for DNA minor groove binding. Therefore, it is evident from these data that the mode of DNA interaction of compound $\mathbf{1 1 b}$ is minor groove binding. 
(A)

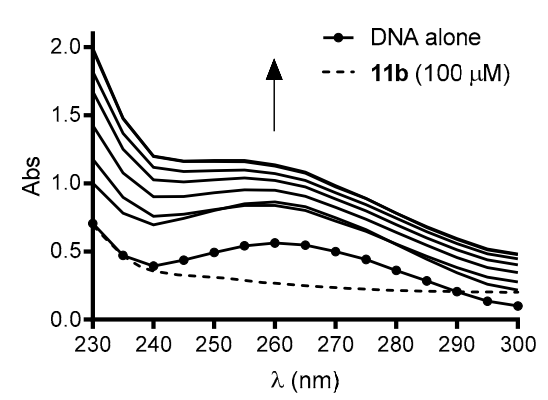

(C)

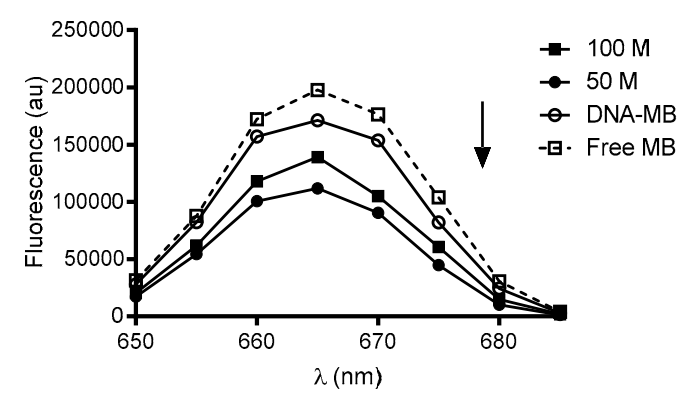

(B)

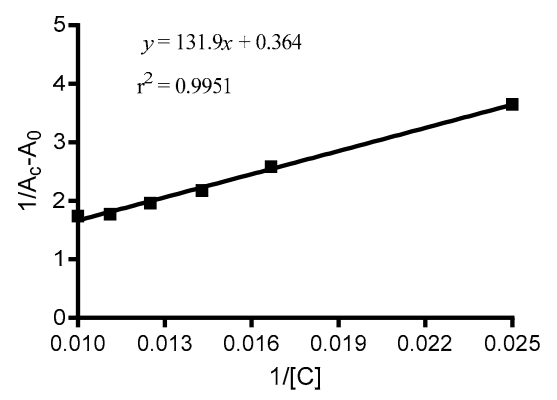

(D)

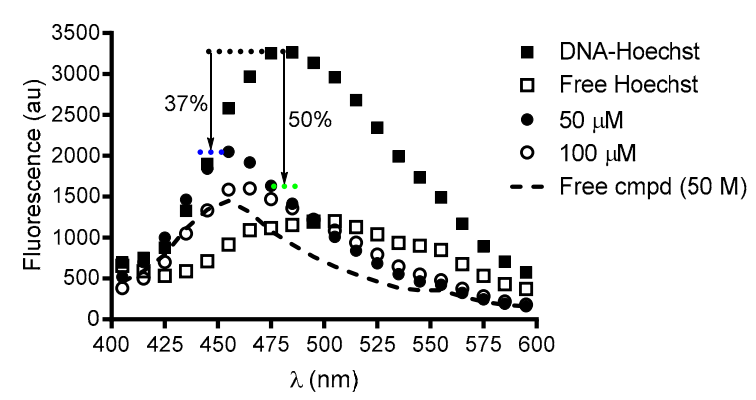

Figure 4. DNA binding affinity results of compound $\mathbf{1 1 b}$ with calf thymus DNA. (A) UV-Vis DNA titration curve, (B) guesthost reciprocal plot of the UV-Vis DNA titration experiment, $(\mathbf{C})$ competitive DNA intercalation assay using methylene blue $(\mathrm{MB})$ and (D) Hoechst assay results for competitive DNA minor groove binding.

\section{Materials and Methods}

\subsection{General Methods and Instrumentation}

All the reagents and solvents used in this study were purchased from Merck (Johannesburg, South Africa) and used as received. In cases of reactions requiring anhydrous conditions the solvents were dried following established literature methods [69]. Formyl hydroxycoumarins $(\mathbf{9}, \mathbf{1 4} \mathbf{a}-\mathbf{c})$ and ferrocenyl amines $(\mathbf{1 0 a}, \mathbf{b})$ were synthesised according to previously published procedures in the literature [13,51-54].

The progress of reactions was monitored by analytical thin layer chromatography (TLC) using Merck F254 silica gel plates coated on aluminium sheets and the plates were visualised under ultraviolet light (UV 254 and $366 \mathrm{~nm}$ ). Crude compounds were purified by column chromatography with activated basic Brockmann alumina $\left(\mathrm{Al}_{3} \mathrm{O}_{4}\right)$ as the stationary phase. The melting points were determined using Reichert melting point apparatus and were uncorrected. ${ }^{1} \mathrm{H}$ and ${ }^{13} \mathrm{C}$ NMR spectra were acquired on Bruker Biospin 300, 400 or $600 \mathrm{MHz}$ spectrometers (Bruker, Ettlingen, Germany) and internally referenced using residual solvent signals of deuterated DMSO- $d_{6}: 2.50 \mathrm{ppm}$ for $1 \mathrm{H}$ and $39.5 \mathrm{ppm}$ for $13 \mathrm{C}$ $\mathrm{NMR}$, or deuterated chloroform $\mathrm{CDCl}_{3}: 7.26 \mathrm{ppm}$ for ${ }^{1} \mathrm{H}$ and $77.2 \mathrm{ppm}$ for ${ }^{13} \mathrm{C} \mathrm{NMR}$ at ambient temperature. Representative 2D NMR spectra (COSY, HSQC and HMBC) were recorded on the 400 or $600 \mathrm{MHz}$ spectrometers (Bruker, Ettlingen, Germany). The spectra were processed using MestReNova software. Chemical shifts of acquired spectra were reported in parts per million (ppm) and J-coupling constants measured in Hertz (Hz). Signal multiplicities were described by the following abbreviations: $\mathrm{s}=\operatorname{singlet}$, $\mathrm{br} \mathrm{s}=\mathrm{broad}$ singlet, $\mathrm{d}=$ doublet, $\mathrm{t}=$ triplet, $\mathrm{q}=$ quartet, and $\mathrm{m}=$ multiplet.

The high-resolution mass spectrometry (HRMS) data were acquired on Waters (Milford, MA, USA) Synapt G2 Mass Spectrometer (Central Analytical Facility, Stellenbosch University, Stellenbosch, South Africa) using electron impact (EI) ionization in the positive ionization mode, and the IR spectra were recorded on PerkinElmer Spectrum 100 FT-IR Spectrometer (Johannesburg, South Africa) in the mid-IR range $\left(640-4000 \mathrm{~cm}^{-1}\right)$. The HPLC purity of the compounds was determined using a reverse-phase Luna ${ }^{\circledR}$ LC column 
( $5 \mu \mathrm{M} \mathrm{C18}, 100 \AA$, $250 \times 4.6 \mathrm{~mm}$ i.d.) on an Agilent 1100 Series HPLC instrument (Agilent, Santa Clara, CA, USA) equipped with a G1315B diode-array detector (DAD), G1311A quaternary pump, G1322A degasser and a G1328B manual injector. The compounds were run by isocratic elution in $10 \% \mathrm{MeOH} / \mathrm{DCM}$ (HPLC grade) for a total running time of 8 min. The calf thymus DNA was sourced from Thermo Fischer Scientific (Johannesburg, South Africa). The UV-Vis and fluorescent spectra for DNA titration experiments were recorded on a SpectraMax M3 microplate reader (v. 8.0.2, 2019, GraphPad Software, San Diego, CA 92108, USA).

\subsection{Synthesis of Target Compounds}

\subsubsection{General Procedure for Synthesis of Acyclic Derivatives 11a,b}

Formyl hydroxycoumarin 9 (1.0 eq.) was added to a solution of ferrocenyl amine 10a or $10 \mathbf{b}$ (1.0 eq.) in ethanol $(15 \mathrm{~mL})$ and the resulting mixture was refluxed for $4 \mathrm{~h}$. The reaction mixture was cooled to room temperature following $4 \mathrm{~h}$ of reflux and sodium borohydride (2.0 eq.) was cautiously added. The reaction was then stirred at room temperature for 15 min and refluxed for another $15 \mathrm{~min}$ after which it was allowed to cool to room temperature. The product was extracted into the aqueous phase with $2 \mathrm{~N} \mathrm{HCl}$ solution $(2 \times 25 \mathrm{~mL})$ and washed with EtOAc $(25 \mathrm{~mL})$. The collected aqueous layers were basified with $1 \mathrm{~N} \mathrm{NaOH}$ solution ( $\mathrm{pH} 10)$ and the product extracted with $\mathrm{DCM}(2 \times 25 \mathrm{~mL})$, dried $\left(\mathrm{Na}_{2} \mathrm{SO}_{4}\right)$ and solvent removed in vacuo to afford the title compound. Column chromatography on basic alumina was employed to purify the compounds where necessary using gradient elution $(\mathrm{DCM} \rightarrow 1: 9 \mathrm{MeOH} / \mathrm{DCM})$.

8-((Ferrocenemethyl)aminomethyl)-7-hydroxycoumarin (11a). Light brown semi-solid. Yield: $235.2 \mathrm{mg}(86 \%) .{ }^{1} \mathrm{H}$ NMR (600 MHz, DMSO- $\left.d_{6}\right) \delta 7.83-7.81\left(\mathrm{~m}, 2 \mathrm{H}, \mathrm{H}_{5}, \mathrm{H}_{7}\right), 7.34(\mathrm{t}$, $\left.J=7.4 \mathrm{~Hz}, 1 \mathrm{H}, \mathrm{H}_{6}\right), 7.10-7.03\left(\mathrm{~m}, 2 \mathrm{H}, \mathrm{H}_{6}, \mathrm{H}_{8}\right), 4.16(\mathrm{~s}, 2 \mathrm{H}, \mathrm{FcH}), 4.13(\mathrm{~s}, 2 \mathrm{H}, \mathrm{FcH}), 4.10(\mathrm{~s}$, $5 \mathrm{H}, \mathrm{FcH}), 4.02\left(\mathrm{~s}, 2 \mathrm{H}, \mathrm{H}_{3^{\prime}}\right), 3.55\left(\mathrm{~s}, 2 \mathrm{H}, \mathrm{H}_{1^{\prime}}\right) ;{ }^{13} \mathrm{C} \mathrm{NMR}\left(150 \mathrm{MHz}, \mathrm{DMSO}-d_{6}\right) \delta 173.1,165.0$, 153.9, 129.4, 124.7, 123.6, 121.5, 115.5, 95.1, 88.9, 68.2 (5C), 67.4 (2C), 66.8 (2C), 46.9, 44.2; IR $\left(\right.$ ATR, $\left.\mathrm{cm}^{-1}\right) v=3080(\mathrm{O}-\mathrm{H}), 2914(\mathrm{~N}-\mathrm{H}) ; \mathrm{HRMS}\left(\mathrm{ESI}^{+}\right) \mathrm{m} / z$ calcd for $\mathrm{C}_{21} \mathrm{H}_{20} \mathrm{FeNO}_{3}[\mathrm{M}+$ $\mathrm{H}]^{+}:$390.0793, Found 390.0782; HPLC purity $>99 \%\left(t_{\mathrm{R}}=2.47 \mathrm{~min}\right)$.

8-((N,N-Dimethylamino)methyl)ferrocenemethyl)-7-hydroxycoumarin (11b). Light brown semisolid. Yield: $121.6 \mathrm{mg}(56 \%) .{ }^{1} \mathrm{H} \mathrm{NMR}\left(600 \mathrm{MHz}, \mathrm{CDCl}_{3}\right) \delta 7.59\left(\mathrm{~d}, J=9.3 \mathrm{~Hz}, 1 \mathrm{H}, \mathrm{H}_{3}\right), 7.23$ $\left(\mathrm{d}, J=8.4 \mathrm{~Hz}, 1 \mathrm{H}, \mathrm{H}_{6}\right), 6.72\left(\mathrm{~d}, J=8.4 \mathrm{~Hz}, 1 \mathrm{H}, \mathrm{H}_{5}\right), 6.10\left(\mathrm{~d}, J=9.3 \mathrm{~Hz}, 1 \mathrm{H}, \mathrm{H}_{4}\right), 4.22(\mathrm{br} \mathrm{s}, 1 \mathrm{H}$, $\mathrm{FcH}), 4.18$ (br s, 1H, FcH), 4.13-4.12 (m, 2H, H $\left.8_{8^{\prime}}\right), 4.09$ (br s, 1H, FcH), 4.04 (s, 5H, FcH), 3.91 $\left(\mathrm{d}, J=13.2 \mathrm{~Hz}, 1 \mathrm{H}, \mathrm{H}_{2^{\prime} \mathrm{a}}\right), 3.79\left(\mathrm{~d}, J=12.7 \mathrm{~Hz}, 1 \mathrm{H}, \mathrm{H}_{1^{\prime} \mathrm{a}}\right), 3.42\left(\mathrm{~d}, J=13.2 \mathrm{~Hz}, 1 \mathrm{H}, \mathrm{H}_{2^{\prime} \mathrm{b}}\right), 2.80$ $\left(\mathrm{d}, J=12.6 \mathrm{~Hz}, 1 \mathrm{H}, \mathrm{H}_{1^{\prime} \mathrm{b}}\right), 2.15\left(\mathrm{~s}, 6 \mathrm{H}, \mathrm{NMe}_{2}\right) ;{ }^{13} \mathrm{C} \mathrm{NMR}\left(150 \mathrm{MHz}, \mathrm{CDCl}_{3}\right) \delta 161.9,153.6$, 144.7, 128.1, 115.1, 110.2, 110.1, 107.4, 100.1, 84.2, 82.6, 69.9, 69.5, 69.2 (5C), 69.0, 58.4, 46.4, 44.9 (2C), 44.6; IR (ATR, cm $\left.{ }^{-1}\right) v=3085(\mathrm{O}-\mathrm{H}), 2918(\mathrm{~N}-\mathrm{H})$; HRMS $\left(\mathrm{ESI}^{+}\right) \mathrm{m} / \mathrm{z}$ calcd for $\mathrm{C}_{24} \mathrm{H}_{27} \mathrm{FeN}_{2} \mathrm{O}_{3}[\mathrm{M}+\mathrm{H}]^{+}:$447.1371, Found 447.1371; HPLC purity $>99 \%\left(t_{\mathrm{R}}=2.46 \mathrm{~min}\right)$.

\subsubsection{General Procedure for Synthesis of Cyclic Coumarin-1,3-oxazin-2-one Derivatives 12a,b}

CDI (1.2 eq.) was added to a solution of a relevant acyclic ferrocenyl aminohydroxycoumarin (11a or 11b) (1.0 eq.) in DCM $(15 \mathrm{~mL})$. The resultant reaction mixture was stirred at room temperature for 1-2 $\mathrm{h}$. After completion of the reaction (TLC), unreacted CDI was quenched by the addition of $0.5 \mathrm{~N} \mathrm{NaOH}$ solution $(15 \mathrm{~mL})$ and the product extracted with DCM $(2 \times 25 \mathrm{~mL})$. The combined organic layers were washed with distilled water $(25 \mathrm{~mL})$, dried $\left(\mathrm{Na}_{2} \mathrm{SO}_{4}\right)$ and the solvent was removed under reduced pressure to furnish the desired carbamate products $\mathbf{1 2} \mathbf{a}, \mathbf{b}$ in high purity.

9-Ferrocenemethyl-9,10-dihydro-2H,8H-chromeno[8,7-e][1,3]oxazine-2,8-dione (12a). Light brown semi-solid. Yield: $146.0 \mathrm{mg}$ (96\%). M.p.: $145.4-148.0{ }^{\circ} \mathrm{C} .{ }^{1} \mathrm{H}$ NMR (400 MHz, DMSO$d_{6} /$ Acetone- $\left.d_{6}\right) \delta 8.03\left(\mathrm{~d}, J=9.3 \mathrm{~Hz}, 1 \mathrm{H}, \mathrm{H}_{3}\right), 7.66\left(\mathrm{~d}, J=8.4 \mathrm{~Hz}, 1 \mathrm{H}, \mathrm{H}_{6}\right), 7.01(\mathrm{~d}, J=8.2 \mathrm{~Hz}$, $\left.1 \mathrm{H}, \mathrm{H}_{5}\right), 6.41\left(\mathrm{~d}, J=9.4 \mathrm{~Hz}, 1 \mathrm{H}, \mathrm{H}_{4}\right), 4.57\left(\mathrm{~s}, 2 \mathrm{H}, \mathrm{H}_{10}\right), 4.47\left(\mathrm{~s}, 2 \mathrm{H}, \mathrm{H}_{1^{\prime}}\right), 4.40(\mathrm{~s}, 2 \mathrm{H}, \mathrm{FcH})$, $4.23(\mathrm{~s}, 5 \mathrm{H}, \mathrm{FcH}), 4.19$ (s, $2 \mathrm{H}, \mathrm{FcH}) ;{ }^{13} \mathrm{C}$ NMR (100 MHz, DMSO- $d_{6} /$ Acetone- $\left.d_{6}\right) \delta 159.3$, 151.6, 150.1, 148.2, 144.1, 128.7, 114.8, 114.2, 112.0, 105.8, 81.4, 69.4, 68.5, 68.2, 47.9, 42.0; IR 
$\left(\right.$ ATR, $\left.\mathrm{cm}^{-1}\right) v=1716(\mathrm{C}=\mathrm{O})$; HRMS $\left(\mathrm{ESI}^{+}\right) \mathrm{m} / z$ calcd for $\mathrm{C}_{21} \mathrm{H}_{20} \mathrm{FeNO}_{3}\left[\mathrm{M}-\mathrm{CO}+\mathrm{H}_{3}\right]^{+}$: 390.0787, Found 390.0781; HPLC purity $>99 \%\left(t_{\mathrm{R}}=2.50 \mathrm{~min}\right)$.

9-(2-((N,N-Dimethylamino)methyl)ferrocenemethyl)-9,10-dihydro-2H,8H-chromeno[8,7-e][1,3] oxazine-2,8-dione (12b). Light yellow solid. Yield: $62.2 \mathrm{mg}(90 \%)$. M.p.: $105.3-108.6{ }^{\circ} \mathrm{C} .{ }^{1} \mathrm{H}$ $\operatorname{NMR}\left(400 \mathrm{MHz}, \mathrm{CDCl}_{3}\right) \delta 7.63\left(\mathrm{~d}, J=9.6 \mathrm{~Hz}, 1 \mathrm{H}, \mathrm{H}_{3}\right), 7.34\left(\mathrm{~d}, J=8.5 \mathrm{~Hz}, 1 \mathrm{H}, \mathrm{H}_{6}\right), 6.91(\mathrm{~d}$, $\left.J=8.5 \mathrm{~Hz}, 1 \mathrm{H}, \mathrm{H}_{5}\right), 6.31\left(\mathrm{~d}, J=9.6 \mathrm{~Hz}, 1 \mathrm{H}, \mathrm{H}_{4}\right), 4.73-4.68\left(\mathrm{~m}, 2 \mathrm{H}, \mathrm{H}_{10}\right), 4.55-4.48(\mathrm{~m}, 2 \mathrm{H}$, $\left.\mathrm{H}_{2^{\prime}}\right), 4.39$ (br s, 1H, FcH), 4.29 (br s, $\left.1 \mathrm{H}, \mathrm{FcH}\right), 4.16(\mathrm{t}, J=2.4 \mathrm{~Hz}, 1 \mathrm{H}, \mathrm{FcH}), 4.13(\mathrm{~s}, 5 \mathrm{H}, \mathrm{FcH})$, 3.83-3.70 (m, 1H, $\left.\mathrm{H}_{1^{\prime} \mathrm{a}}\right), 3.15-3.03\left(\mathrm{~m}, 1 \mathrm{H}, \mathrm{H}_{1^{\prime} \mathrm{b}}\right), 2.19$ (s, 6H, NMe $)$; ${ }^{13} \mathrm{C} \mathrm{NMR}(100 \mathrm{MHz}$, $\left.\mathrm{CDCl}_{3}\right) \delta 160.0,152.3,150.5,149.4,143.3,127.9,114.9,114.8,112.7,106.5,80.9(2 \mathrm{C}), 71.9$, $71.2,69.5$ (5C), 67.8, 57.2, 46.9, 44.4 (2C), 41.9; IR (ATR, $\left.\mathrm{cm}^{-1}\right) v=1720(\mathrm{C}=\mathrm{O})$; HRMS $\left(\mathrm{ESI}^{+}\right)$ $m / z$ calcd for $\mathrm{C}_{24} \mathrm{H}_{25} \mathrm{FeN}_{2} \mathrm{O}_{4}[\mathrm{M}+\mathrm{H}]^{+}:$473.1164, Found $473.1159 ;$;); HPLC purity $>99 \%$ $\left(t_{\mathrm{R}}=3.43 \mathrm{~min}\right)$.

3.2.3. Synthesis of 9-(2-((N,N-Dimethylamino)methyl)ferrocenemethyl)-9,10dihydrochromeno[8,7-e][1,3] oxazin-2 $(8 \mathrm{H})$-one $(\mathbf{1 3})$

Aminohydroxycoumarin $\mathbf{1 1 b}$ (1.0 eq.) in $\mathrm{CHCl}_{3}(20 \mathrm{~mL})$ was refluxed with paraformaldehyde (1.0 eq.) for $12 \mathrm{~h}$, after which the reaction was cooled to room temperature. The reaction mixture was diluted with $\mathrm{CHCl}_{3}(50 \mathrm{~mL})$ and successively washed with $1 \mathrm{~N} \mathrm{NaOH}$ solution $(2 \times 25 \mathrm{~mL})$ and distilled water $(25 \mathrm{~mL})$. The organic layer was dried $\left(\mathrm{Na}_{2} \mathrm{SO}_{4}\right)$ and the solvent removed in vacuo to afford the target compound in high purity as a light yellow semi-solid. Yield: $94.3 \mathrm{mg}(68 \%) .{ }^{1} \mathrm{H}$ NMR $\left(600 \mathrm{MHz}, \mathrm{CDCl}_{3}\right) \delta 7.62(\mathrm{~d}, J=9.4 \mathrm{~Hz}$, $\left.1 \mathrm{H}, \mathrm{H}_{3}\right), 7.24\left(\mathrm{~s}, 1 \mathrm{H}, \mathrm{H}_{6}\right), 6.76\left(\mathrm{~d}, J=8.5 \mathrm{~Hz}, 1 \mathrm{H}, \mathrm{H}_{5}\right), 6.22\left(\mathrm{~d}, J=9.4 \mathrm{~Hz}, 1 \mathrm{H}, \mathrm{H}_{4}\right), 4.96(\mathrm{~s}$, $\left.2 \mathrm{H}, \mathrm{H}_{8}\right), 4.26\left(\mathrm{br} \mathrm{s}, 1 \mathrm{H}, \mathrm{H}, \mathrm{H}_{10 \mathrm{a}}\right), 4.22-4.21\left(\mathrm{~m}, 2 \mathrm{H}, \mathrm{FcH}, \mathrm{H}_{8 \mathrm{~b}}\right), 4.12(\mathrm{t}, J=2.5 \mathrm{~Hz}, 1 \mathrm{H}, \mathrm{FcH})$, $4.06(\mathrm{~s}, 1 \mathrm{H}, \mathrm{FcH}), 4.01(\mathrm{~s}, 5 \mathrm{H}, \mathrm{FcH}), 3.77\left(\mathrm{~d}, J=13.3 \mathrm{~Hz}, 1 \mathrm{H}, \mathrm{H}_{2^{\prime} \mathrm{a}}\right), 3.73(\mathrm{~d}, J=13.3 \mathrm{~Hz}, 1 \mathrm{H}$, $\left.\mathrm{H}_{2^{\prime} \mathrm{b}}\right), 3.31-3.27\left(\mathrm{~m}, 1 \mathrm{H}, \mathrm{H}_{1^{\prime} \mathrm{a}}\right), 3.10\left(\mathrm{~d}, J=12.9 \mathrm{~Hz}, 1 \mathrm{H}, \mathrm{H}_{2^{\prime} \mathrm{b}}\right), 2.07\left(\mathrm{~s}, 6 \mathrm{H}, \mathrm{NMe}_{2}\right) ;{ }^{13} \mathrm{C} \mathrm{NMR}$ $\left(150 \mathrm{MHz}, \mathrm{CDCl}_{3}\right) \delta 161.3,158.0,152.8,144.1,126.5,113.7,112.6,112.2,108.7,84.4,83.3,82.9$, 70.8, 70.3, 69.4 (5C), 67.4, 57.5, 49.8, 45.3 (2C), 44.6; IR (ATR, $\mathrm{cm}^{-1}$ ) v = 1238 (C-O), 1116 (C-N); HRMS $\left(\mathrm{ESI}^{+}\right) m / z$ calcd for $\mathrm{C}_{25} \mathrm{H}_{27} \mathrm{FeN}_{2} \mathrm{O}_{3}[\mathrm{M}+\mathrm{H}]^{+}:$459.1366, Found 459.1363; HPLC purity $>99 \%\left(t_{R}=3.40 \mathrm{~min}\right)$.

\subsubsection{Synthesis of Acyclic Ferrocenyl Aminocoumarin-4-ols 15a-d}

Compounds 15a-d were prepared from substituted 3-formyl-4-hydroxycoumarins 14a-c and ferrocenyl amines $10 \mathbf{a}, \mathbf{b}$ following the reaction conditions described for synthesis acyclic derivatives 11a,b.

3-((Ferrocenemethyl)aminomethyl)-coumarin-4-ol (15a). Light brown semi-solid: $235.2 \mathrm{mg}$ (86\%). ${ }^{1} \mathrm{H}$ NMR (600 MHz, DMSO- $\left.d_{6}\right) \delta 7.83-7.81\left(\mathrm{~m}, 2 \mathrm{H}, \mathrm{H}_{5}, \mathrm{H}_{7}\right), 7.34(\mathrm{t}, J=7.4 \mathrm{~Hz}, 1 \mathrm{H}$, $\left.\mathrm{H}_{6}\right), 7.10-7.03\left(\mathrm{~m}, 2 \mathrm{H}, \mathrm{H}_{5}, \mathrm{H}_{8}\right), 4.16(\mathrm{~s}, 2 \mathrm{H}, \mathrm{FcH}), 4.13(\mathrm{~s}, 2 \mathrm{H}, \mathrm{FcH}), 4.10(\mathrm{~s}, 5 \mathrm{H}, \mathrm{FcH}), 4.02$ $\left(\mathrm{s}, 2 \mathrm{H}, \mathrm{H}_{1^{\prime}}\right), 3.55\left(\mathrm{~s}, 2 \mathrm{H}, \mathrm{H}_{1^{\prime}}\right) ;{ }^{3} \mathrm{C}$ NMR $\left(150 \mathrm{MHz}\right.$, DMSO- $\left.d_{6}\right) \delta 173.1,165.0,153.9,129.4$, 124.7, 123.6, 121.5, 115.5, 95.1, 88.9, 68.2 (5C), 67.4 (2C), 66.8 (2C), 46.9, 44.2; IR (ATR, $\mathrm{cm}^{-1}$ ) $v=3083(\mathrm{O}-\mathrm{H}), 2915(\mathrm{~N}-\mathrm{H})$; HRMS $\left(\mathrm{ESI}^{+}\right) \mathrm{m} / z$ calcd for $\mathrm{C}_{21} \mathrm{H}_{20} \mathrm{FeNO}_{3}[\mathrm{M}+\mathrm{H}]^{+}$: 390.0793, Found 390.0779; HPLC purity $>91 \%\left(t_{R}=2.47 \mathrm{~min}\right)$.

3-((2-((N,N-Dimethylamino)methyl)ferrocenemethyl)aminomethyl)-coumarin-4-ol (15b). Brown semi-solid: $350.2 \mathrm{mg}(68 \%) .{ }^{1} \mathrm{H}$ NMR $\left(600 \mathrm{MHz}, \mathrm{CDCl}_{3} \delta 7.83\left(\mathrm{dd}, J=7.7,1.1 \mathrm{~Hz}, 1 \mathrm{H}, \mathrm{H}_{5}\right)\right.$, $7.40\left(\mathrm{td}, J=7.7,1.4 \mathrm{~Hz}, 1 \mathrm{H}, \mathrm{H}_{7}\right), 7.17\left(\mathrm{~d}, J=7.8 \mathrm{~Hz}, 1 \mathrm{H}, \mathrm{H}_{8}\right), 7.14\left(\mathrm{t}, J=7.5 \mathrm{~Hz}, 1 \mathrm{H}, \mathrm{H}_{6}\right), 4.34$ (s, 1H, FcH), 4.19 (br s, 1H, FcH), 4.20-4.17 (m, 2H, $\left.\mathrm{H}_{3^{\prime} \mathrm{a}}, \mathrm{FcH}\right), 4.13(\mathrm{t}, J=2.4 \mathrm{~Hz}, 1 \mathrm{H}, \mathrm{FcH})$, $4.11(\mathrm{~s}, 5 \mathrm{H}, \mathrm{FcH}), 4.09\left(\mathrm{~d}, J=8.8 \mathrm{~Hz}, 2 \mathrm{H}, \mathrm{H}_{2^{\prime}}\right), 3.90-3.89\left(\mathrm{~m}, 2 \mathrm{H}, \mathrm{H}_{1^{\prime} \mathrm{a}}, \mathrm{H}_{3^{\prime} \mathrm{b}}\right), 2.88(\mathrm{~d}, J=13.0$ $\left.\mathrm{Hz}, 1 \mathrm{H}, \mathrm{H}_{1^{\prime} \mathrm{b}}\right), 2.16\left(\mathrm{~s}, 6 \mathrm{H}, \mathrm{NMe}_{2}\right) ;{ }^{13} \mathrm{C}$ NMR $\left(150 \mathrm{MHz}, \mathrm{CDCl}_{3}\right) \delta 176.1,165.8,154.4,131.1$, 124.5, 122.8, 122.0, 116.6, 100.1, 88.8, 84.1, 72.0 (2C), 69.7 (5C), 67.3, 58.1, 45.7, 44.2, 43.7 (2C); IR $\left(\right.$ ATR, $\left.\mathrm{cm}^{-1}\right) v=2820(\mathrm{O}-\mathrm{H}), 2774(\mathrm{~N}-\mathrm{H}) ; \mathrm{HRMS}\left(\mathrm{ESI}^{+}\right) \mathrm{m} / z$ calcd for $\mathrm{C}_{24} \mathrm{H}_{27} \mathrm{FeN}_{2} \mathrm{O}_{3}[\mathrm{M}$ $+\mathrm{H}]^{+}:$447.1371, Found 447.1371; HPLC purity $>96 \%\left(t_{\mathrm{R}}=2.46 \mathrm{~min}\right)$. 
3-((2-((N,N-Dimethylamino)methyl)ferrocenemethyl)aminomethyl)-6-fluoro-4-hydroxycoumarin (15c). Light brown semi-solid. $109.0 \mathrm{mg}(64 \%) .{ }^{1} \mathrm{H} \mathrm{NMR}\left(600 \mathrm{MHz}, \mathrm{CDCl}_{3}\right) \delta 7.48$ (dd, $\left.J=8.6,2.9 \mathrm{~Hz}, 1 \mathrm{H}, \mathrm{H}_{5}\right), 7.14-7.09\left(\mathrm{~m}, 2 \mathrm{H}, \mathrm{H}_{7}, \mathrm{H}_{8}\right), 4.33$ (br s, $\left.1 \mathrm{H}, \mathrm{FcH}\right), 4.20$ (br s, $1 \mathrm{H}$, $\mathrm{FcH}), 4.18\left(\mathrm{~d}, J=13.4 \mathrm{~Hz}, 1 \mathrm{H}, \mathrm{H}_{2^{\prime} \mathrm{a}}\right), 4.13(\mathrm{t}, J=2.4 \mathrm{~Hz}, 1 \mathrm{H}, \mathrm{FcH}), 4.11(\mathrm{~s}, 5 \mathrm{H}, \mathrm{FcH}), 4.07(\mathrm{~d}$, $\left.J=13.0 \mathrm{~Hz}, 2 \mathrm{H}, \mathrm{H}_{3^{\prime}}\right), 3.87\left(\mathrm{~d}, J=13.1 \mathrm{~Hz}, 2 \mathrm{H}, \mathrm{H}_{1^{\prime} \mathrm{a}}, \mathrm{H}_{2^{\prime} \mathrm{b}}\right), 2.89\left(\mathrm{~d}, J=13.0 \mathrm{~Hz}, 1 \mathrm{H}, \mathrm{H}_{1^{\prime} \mathrm{b}}\right)$, $2.16\left(\mathrm{~s}, 6 \mathrm{H}, \mathrm{NMe}_{2}\right) ;{ }^{13} \mathrm{C} \mathrm{NMR}\left(150 \mathrm{MHz}, \mathrm{CDCl}_{3}\right) \delta 174.9,165.8,159.3,157.7,150.3,123.2(\mathrm{~d}$, $J=7.9 \mathrm{~Hz}), 118.3(\mathrm{~d}, J=24.8 \mathrm{~Hz}), 118.0(\mathrm{~d}, J=7.9 \mathrm{~Hz}), 109.9(\mathrm{~d}, J=23.8 \mathrm{~Hz}), 89.2,84.1,72.0$, 71.9, 69.6 (5C), 67.3, 58.1, 46.0, 44.2 (2C), 43.5; IR (ATR, $\mathrm{cm}^{-1}$ ) v = $3076(\mathrm{O}-\mathrm{H}), 2915(\mathrm{~N}-\mathrm{H})$; HRMS $\left(\mathrm{ESI}^{+}\right) \mathrm{m} / z$ calcd for $\mathrm{C}_{24} \mathrm{H}_{26} \mathrm{FFeN}_{2} \mathrm{O}_{3}[\mathrm{M}+\mathrm{H}]^{+}:$465.1279, Found 465.1279; HPLC purity $>99 \%\left(t_{\mathrm{R}}=2.48 \mathrm{~min}\right)$.

3-((2-((N,N-Dimethylamino)methyl)ferrocenemethyl)aminomethyl)-6-chloro-4-hydroxycoumarin (15d). Light brown semi-solid. Yield: $174.4 \mathrm{mg}(66 \%) .{ }^{1} \mathrm{H} \mathrm{NMR}\left(600 \mathrm{MHz}, \mathrm{CDCl}_{3}\right) \delta$ $7.75\left(\mathrm{~d}, J=2.5 \mathrm{~Hz}, 1 \mathrm{H}, \mathrm{H}_{5}\right), 7.31\left(\mathrm{dd}, J=8.7,2.6 \mathrm{~Hz}, 1 \mathrm{H}, \mathrm{H}_{7}\right), 7.09\left(\mathrm{~d}, J=8.7 \mathrm{~Hz}, 1 \mathrm{H}, \mathrm{H}_{4}\right), 4.31$ (br s, $1 \mathrm{H}, \mathrm{FcH}), 4.21$ (d, J = $\left.13.3 \mathrm{~Hz}, 1 \mathrm{H}_{3^{\prime} \mathrm{a}}\right), 4.19$ (br s, 1H, FcH), $4.11(\mathrm{~d}, J=4.7 \mathrm{~Hz}, 6 \mathrm{H}, \mathrm{FcH})$, 4.06-4.01 (m, 2H, $\left.\mathrm{H}_{2^{\prime}}\right), 3.88\left(\mathrm{~d}, J=13.0 \mathrm{~Hz}, 1 \mathrm{H}, \mathrm{H}_{1^{\prime} \mathrm{a}}\right), 3.85\left(\mathrm{~d}, J=13.3 \mathrm{~Hz}, 1 \mathrm{H}, \mathrm{H}_{3^{\prime} \mathrm{b}}\right), 2.87$ $\left(\mathrm{d}, J=13.0 \mathrm{~Hz}, 1 \mathrm{H}, \mathrm{H}_{1^{\prime} \mathrm{b}}\right), 2.15\left(\mathrm{~s}, 6 \mathrm{H}, \mathrm{NMe}_{2}\right) ;{ }^{13} \mathrm{C} \mathrm{NMR}\left(150 \mathrm{MHz}, \mathrm{CDCl}_{3}\right) \delta 174.6,165.5$, $152.7,130.9,128.2,124.2,123.4,118.1,100.1,89.4,84.1,72.0,71.9,69.6$ (5C), 67.3, 58.1, 46.0, 44.2 (2C), 43.3; IR (ATR, $\mathrm{cm}^{-1}$ ) v = $3070(\mathrm{O}-\mathrm{H}), 2923(\mathrm{~N}-\mathrm{H})$; HRMS $\left(\mathrm{ESI}^{+}\right) \mathrm{m} / \mathrm{z}$ calcd for $\mathrm{C}_{24} \mathrm{H}_{26} \mathrm{ClFeN}_{2} \mathrm{O}_{3}[\mathrm{M}+\mathrm{H}]^{+}:$481.0976, Found 481.1568; HPLC purity $>99 \%\left(t_{\mathrm{R}}=2.47 \mathrm{~min}\right)$.

\subsubsection{Synthesis of Ferrocenyl Coumarin-1,3-oxazin-2-one Derivatives 16a-d}

Compounds $\mathbf{1 6 a}-\mathbf{d}$ were synthesized according to the general procedure employed for the synthesis of coumarin-1,3-oxazin-2-one derivatives 12a,b from aminocoumarin-4ols 15a-d.

3-Ferrocenemethyl-3,4-dihydro-2H,5H-chromeno[3,4-e][1,3]oxazine-2,5-dione (16a). Light brown semi-solid. Yield: $41.0 \mathrm{mg}(68 \%) .{ }^{1} \mathrm{H} \mathrm{NMR}\left(600 \mathrm{MHz}, \mathrm{CDCl}_{3}\right) \delta 7.78(\mathrm{dd}, J=8.1,1.4 \mathrm{~Hz}$, $\left.1 \mathrm{H}, \mathrm{H}_{7}\right), 7.51\left(\mathrm{td}, J=8.4,1.4 \mathrm{~Hz}, 1 \mathrm{H}, \mathrm{H}_{8}\right), 7.35-7.33\left(\mathrm{~m}, 2 \mathrm{H}, \mathrm{H}_{9}, \mathrm{H}_{10}\right), 4.40\left(\mathrm{~s}, 2 \mathrm{H}, \mathrm{H}_{4}\right), 4.26$ (br s, 2H, FcH), 4.12 (br s, 9H, FcH, $\left.\mathrm{H}_{1^{\prime}}\right) ;{ }^{13} \mathrm{C} \mathrm{NMR}\left(150 \mathrm{MHz}, \mathrm{CDCl}_{3}\right) \delta 159.8,155.9,153.2$, 147.1, 133.1, 124.9, 122.8, 117.0, 113.0, 98.2, 80.1, 70.0 (2C), 69.2 (2C), 68.9 (5C), 49.3, 43.3; IR $\left(\mathrm{ATR}, \mathrm{cm}^{-1}\right) v=1738(\mathrm{C}=\mathrm{O})$; HRMS $\left(\mathrm{ESI}^{+}\right) \mathrm{m} / z$ calcd for $\mathrm{C}_{22} \mathrm{H}_{18} \mathrm{FeNO}_{4}[\mathrm{M}+\mathrm{H}]^{+}: 416.0586$, Found 416.0586; HPLC purity $>98 \%\left(t_{\mathrm{R}}=3.03 \mathrm{~min}\right)$.

3-(2-((N,N-Dimethylamino)methyl)ferrocenemethyl)-3,4-dihydro-2H,5H-chromeno[3,4-e][1,3]oxazine2,5-dione (16b). Light brown semi-solid. Yield: $37.3 \mathrm{mg}(75 \%) .{ }^{1} \mathrm{H} \mathrm{NMR}\left(600 \mathrm{MHz}, \mathrm{CDCl}_{3}\right) \delta$ $7.88\left(\mathrm{~d}, J=7.8 \mathrm{~Hz}, 1 \mathrm{H}, \mathrm{H}_{7}\right), 7.58\left(\mathrm{t}, J=7.6 \mathrm{~Hz}, 1 \mathrm{H}, \mathrm{H}_{8}\right), 7.33-7.33\left(\mathrm{~m}, 2 \mathrm{H}, \mathrm{H}_{9}, \mathrm{H}_{10}\right), 4.81(\mathrm{~d}$, $\left.J=14.5 \mathrm{~Hz}, 1 \mathrm{H}, \mathrm{H}_{4 \mathrm{a}}\right), 4.38\left(\mathrm{~d}, J=14.5 \mathrm{~Hz}, 1 \mathrm{H}, \mathrm{H}_{4 \mathrm{~b}}\right), 4.33-4.31\left(\mathrm{~m}, 2 \mathrm{H}, \mathrm{H}_{2}{ }^{\prime} \mathrm{a}, \mathrm{FcH}\right), 4.28(\mathrm{~s}, 1 \mathrm{H}$, $\mathrm{FcH}), 4.21$ (br s, 1H, FcH), 4.14-4.13 (m, 6H, H $2^{\prime}$ b, $\left.\mathrm{FcH}\right), 3.66$ (d, J = $\left.12.4 \mathrm{~Hz}, 1 \mathrm{H}, \mathrm{H}_{1^{\prime} \mathrm{a}}\right), 2.90$ (br s, 1H, $\left.\mathrm{H}_{1^{\prime} \mathrm{b}}\right), 2.10$ (s, 6H, $\left.\mathrm{NMe}_{2}\right) ;{ }^{13} \mathrm{C} \mathrm{NMR}\left(150 \mathrm{MHz}, \mathrm{CDCl}_{3}\right) \delta 159.8,155.6,153.2,147.6$, $132.8,124.8,122.7,117.0,113.1,98.8,88.5,80.5,72.0,71.3,69.5$ (5C), 67.5, 57.5, 47.2 (2C), 44.9, 42.5; IR (ATR, $\left.\mathrm{cm}^{-1}\right) v=1752(\mathrm{C}=\mathrm{O})$; HRMS $\left(\mathrm{ESI}^{+}\right) \mathrm{m} / \mathrm{z}$ calcd for $\mathrm{C}_{24} \mathrm{H}_{27} \mathrm{ClFeN}_{2} \mathrm{O}_{3} \mathrm{Na}[\mathrm{M}$ $\left.-\mathrm{CO}+\mathrm{NaCl}+\mathrm{H}_{3}\right]^{+}: 505.0952$, Found 505.1424; HPLC purity $>91 \%\left(t_{\mathrm{R}}=2.43 \mathrm{~min}\right)$.

3-(2-((N,N-Dimethylamino)methyl)ferrocenemethyl)-9-fluoro-3,4-dihydro-2H,5H-chromeno[3,4-e][1,3] oxazine-2,5-dione (16c). Light brown semi-solid. Yield: $16.6 \mathrm{mg}(36 \%) .{ }^{1} \mathrm{H} \mathrm{NMR}(600 \mathrm{MHz}$, $\left.\mathrm{CDCl}_{3}\right) \delta 7.56\left(\mathrm{dd}, J=8.0,2.8 \mathrm{~Hz}, 1 \mathrm{H}, \mathrm{H}_{10}\right), 7.33-729\left(\mathrm{~m}, 2 \mathrm{H}, \mathrm{H}_{7}, \mathrm{H}_{18}\right), 4.79(\mathrm{~d}, J=14.5 \mathrm{~Hz}$, $\left.1 \mathrm{H}, \mathrm{H}_{4 \mathrm{a}}\right), 4.39$ (d, J = 14.5 Hz, 1H, H $\left.\mathrm{H}_{4 \mathrm{~b}}\right), 4.34-4.29$ (m, 2H, H $\left.2^{\prime}{ }_{\mathrm{a}}, \mathrm{FcH}\right), 4.18(\mathrm{~s}, 1 \mathrm{H}, \mathrm{FcH}), 4.15-$ 4.09 (m, 7H, H $2^{\prime}$ b,$\left.F c H\right), 3.64\left(\mathrm{~d}, J=12.6 \mathrm{~Hz}, 1 \mathrm{H}, \mathrm{H}_{1^{\prime} \mathrm{a}}\right), 2.84\left(\mathrm{~d}, J=12.6 \mathrm{~Hz}, 1 \mathrm{H}, \mathrm{H}_{1^{\prime} \mathrm{b}}\right), 2.07$ (s, $6 \mathrm{H}) ;{ }^{13} \mathrm{C}$ NMR $\left(150 \mathrm{MHz}, \mathrm{CDCl}_{3}\right) \delta 159.5,158.2,154.8,149.3,147.2,120.4(\mathrm{~d}, J=24.6 \mathrm{~Hz})$, $118.7(\mathrm{~d}, J=8.3 \mathrm{~Hz}), 114.1,108.6(\mathrm{~d}, J=25.9 \mathrm{~Hz}), 99.8,84.9,80.3,72.1,71.3,69.5(5 \mathrm{C}), 67.4$, 57.6, 47.3, 45.0 (2C), 42.5; IR (ATR, $\left.\mathrm{cm}^{-1}\right) v=1717(\mathrm{C}=\mathrm{O})$; HRMS $\left(\mathrm{ESI}^{+}\right) \mathrm{m} / \mathrm{z}$ calcd for $\mathrm{C}_{24} \mathrm{H}_{26} \mathrm{ClFFeN}_{2} \mathrm{O}_{3} \mathrm{Na}\left[\mathrm{M}-\mathrm{CO}+\mathrm{NaCl}+\mathrm{H}_{3}\right]^{+}$: 523.1338, Found 523.1338; HPLC purity > $91 \%\left(t_{\mathrm{R}}=2.60 \mathrm{~min}\right)$. 
3-(2-((N,N-Dimethylamino)methyl)ferrocenemethyl)-9-chloro-3,4-dihydro-2H,5H-chromeno[3,4-e] [1,3]oxazine-2,5-dione (16d). Light brown semi-solid. Yield: $17.3 \mathrm{mg}(49 \%) .{ }^{1} \mathrm{H}$ NMR $\left(600 \mathrm{MHz}, \mathrm{CDCl}_{3}\right) \delta 8.06\left(\mathrm{~d}, J=2.4 \mathrm{~Hz}, 1 \mathrm{H}, \mathrm{H}_{10}\right), 7.71\left(\mathrm{dd}, J=8.8,2.4 \mathrm{~Hz}, 1 \mathrm{H}, \mathrm{H}_{8}\right), 7.47(\mathrm{~d}$, $\left.J=8.9 \mathrm{~Hz}, 1 \mathrm{H}, \mathrm{H}_{7}\right), 4.98\left(\mathrm{~d}, J=14.5 \mathrm{~Hz}, 1 \mathrm{H}, \mathrm{H}_{4 \mathrm{a}}\right), 4.59\left(\mathrm{~d}, J=14.5 \mathrm{~Hz}, 1 \mathrm{H}, \mathrm{H}_{4 \mathrm{~b}}\right), 4.51-4.49$ $\left(\mathrm{m}, 2 \mathrm{H}, \mathrm{FcH}, \mathrm{H}_{2}^{\prime} \mathrm{a}\right), 4.38$ (br s, 1H, FcH), 4.33-4.32 (m, 7H, FcH, $\left.\mathrm{H}_{2}{ }^{\prime} \mathrm{b}\right), 3.83$ (d, J = $12.5 \mathrm{~Hz}$, $\left.1 \mathrm{H}, \mathrm{H}_{1^{\prime} \mathrm{a}}\right), 3.03\left(\mathrm{~d}, J=12.6 \mathrm{~Hz}, 1 \mathrm{H}, \mathrm{H}_{1^{\prime} \mathrm{b}}\right), 2.27\left(\mathrm{~s}, 6 \mathrm{H}, \mathrm{NMe}_{2}\right) ;{ }^{13} \mathrm{C} \mathrm{NMR}\left(150 \mathrm{MHz}, \mathrm{CDCl}_{3}\right) \delta$ $159.2,154.5,151.4,147.1,132.9,130.5,122.3,118.4,114.2,99.8,84.9,80.3,72.1,71.3,69.5$ (5C), 67.4, 57.6, 47.2, $45.0(2 \mathrm{C}), 42.4$; IR (ATR, $\left.\mathrm{cm}^{-1}\right) v=1717(\mathrm{C}=\mathrm{O})$; HRMS $\left(\mathrm{ESI}^{+}\right) \mathrm{m} / \mathrm{z}$ calcd for $\mathrm{C}_{24} \mathrm{H}_{26} \mathrm{Cl}_{2} \mathrm{FeN}_{2} \mathrm{O}_{3} \mathrm{Na}\left[\mathrm{M}-\mathrm{CO}+\mathrm{NaCl}+\mathrm{H}_{3}\right]^{+}$: 539.1057, Found 539.1057; HPLC purity $>$ $99 \%\left(t_{\mathrm{R}}=2.58 \mathrm{~min}\right)$.

3.2.6. Synthesis of 7-(2-((N,N-Dimethylamino)methyl)ferrocenemethyl)-7,8-dihydro-6H$[1,3]$ dioxolo $\left[4^{\prime}, 5^{\prime}: 4,5\right]$ benzo[1,2-e][1,3]oxazine (19)

Compound 19 was synthesized from sesamol 18 (1.0 eq) and paraformaldehyde (2.0 eq.) following the procedure described for the synthesis of coumarin-oxazine 13. Brown semi-solid. Yield: $135.5 \mathrm{mg}(85 \%) .{ }^{1} \mathrm{H} \mathrm{NMR}\left(400 \mathrm{MHz}, \mathrm{CDCl}_{3}\right) \delta 6.39\left(\mathrm{~s}, 1 \mathrm{H}, \mathrm{H}_{9}\right)$, $6.38\left(\mathrm{~s}, 1 \mathrm{H}, \mathrm{H}_{4}\right), 5.87\left(\mathrm{~s}, 2 \mathrm{H}, \mathrm{H}_{2}\right), 4.85-4.77\left(\mathrm{~m}, 2 \mathrm{H}, \mathrm{H}_{6}\right), 4.25$ (br s, $\left.1 \mathrm{H}, \mathrm{FcH}\right), 4.22$ (br s, 1H, $\mathrm{FcH}), 4.12-4.11$ (m, 1H, FcH), 4.02 (s, 5H, FcH), 3.93 (br s, 2H, H8), 3.73 (s, 2H, H $\left.2_{2^{\prime}}\right), 3.30$ $\left(\mathrm{d}, J=12.9 \mathrm{~Hz}, 1 \mathrm{H}, \mathrm{H}_{1^{\prime} \mathrm{a}}\right), 3.19\left(\mathrm{~d}, J=12.9 \mathrm{~Hz}, 1 \mathrm{H}, \mathrm{H}_{1^{\prime} \mathrm{b}}\right), 2.16\left(\mathrm{~s}, 6 \mathrm{H}, \mathrm{NMe}_{2}\right)$; ${ }^{13} \mathrm{C} \mathrm{NMR}$ $\left(100 \mathrm{MHz}, \mathrm{CDCl}_{3}\right) \delta 148.8,146.6,141.5,111.7,106.9,100.8,98.5,84.2,83.9,82.4,70.7,70.3$, 69.4 (5C), 67.2, 57.4, 49.3, 49.3, 45.4 (2C); IR (ATR, $\mathrm{cm}^{-1}$ ) v = 1241 (C-O), 1141 (C-N), HRMS $\left(\mathrm{ESI}^{+}\right) \mathrm{m} / z$ calcd for $\mathrm{C}_{23} \mathrm{H}_{27} \mathrm{FeN}_{2} \mathrm{O}_{3}[\mathrm{M}+\mathrm{H}]^{+}:$435.1366, Found 435.1370; HPLC purity > $99 \%\left(t_{\mathrm{R}}=2.40 \mathrm{~min}\right)$.

\subsection{Biological Evaluation Assays}

\subsubsection{D7 P. falciparum Antiplasomidal Evaluation}

The 3D7 P. falciparum parasites were grown in a RPMI1640 medium containing $25 \mathrm{mM}$ HEPES (Lonza, Switzerland), 2-4\% (v/v) human erythrocytes, $0.5 \%(w / v)$ Albumax II (Thermo Fisher Scientific, Waltham, MA, USA), $22 \mathrm{mM}$ glucose, $0.65 \mathrm{mM}$ hypoxanthine and $0.05 \mathrm{mg} / \mathrm{mL}$ gentamicin and kept at $37{ }^{\circ} \mathrm{C}$ under a $5 \% \mathrm{CO}_{2}, 5 \% \mathrm{O}_{2}$ and $90 \% \mathrm{~N}_{2}$ atmosphere. The cultures were transferred to 96-well plates and then treated with serial dilutions, in DMSO, of the test compounds and chloroquine as a positive control. Following a 48-h incubation period under these conditions, the plasmocidal activity of each compound was quantified in terms of $\mathrm{IC}_{50}$ values according to previously reported procedures using the plasmodium lactate dehydrogenase (pLDH) enzyme assay $[47,70]$.

\subsubsection{T. b. Brucei 427 Antitrypanosomal Assay}

Trypomastigotes of the T. $b$. brucei 427 strain were cultured in an IMDM medium (Lonza, Switzerland) supplemented with 10\% fetal serum, HMI-9 supplement, hypoxanthine and penicillin/streptomycin in a $10 \% \mathrm{CO}_{2}$ incubator maintained at $37{ }^{\circ} \mathrm{C}$. The parasites were seeded into 96-well plates and incubated with varying concentrations of the test compounds and control drug (pentamidine) for a period of $24 \mathrm{~h}$ after which resazurin was added to a final concentration of $50 \mu \mathrm{M}$. Following a further $24-\mathrm{h}$ incubation under the same conditions, the antitrypanosomal activity of the compounds was quantified in terms of the $\mathrm{IC}_{50}$ values according to the previously described procedure [46].

\subsubsection{Antiproliferative Assay against the HCC70 Triple-Negative Breast Cancer Cell Line}

The compounds were evaluated for anticancer efficacy against HCC70 triple-negative breast cancer cells (ATCC ${ }^{\circledR}$ CRL-2315 ${ }^{\mathrm{TM}}$ ) that were cultured and screened according to the methods used in the previous studies [46,47].

\subsection{4. $\beta$-Hematin Binding Assay for Hemozoin Inhibition}

Varying concentrations of the tool compound (11b) and chloroquine dissolved in DMSO were mixed with $100 \mu \mathrm{L}$ of $220 \mu \mathrm{M}$ hematin solution (prepared from hemin from 
porcine in DMSO and 1.0 M acetate buffer, $\mathrm{pH} 4.8$ ) in a 96-well plate. Hemozoin formation was induced by adding $20 \mu \mathrm{L}$ of $30 \mu \mathrm{M} \mathrm{NP}-40$ detergent followed by 6-h incubation of the plate at $37{ }^{\circ} \mathrm{C}$ with gentle shaking. Following incubation, a solution of $50 \%$ pyridine $(v / v)$, $20 \%$ acetone $(v / v), 10 \%$ distilled water and $20 \% 200 \mathrm{mM}$ HEPES buffer ( $\mathrm{pH} 7.4)$ were added to each well to analyse hemozoin formation by the pyridine-ferrichrome method $[60,61]$. Dispersion of the formed hemozoin solid was facilitated by adding $50 \mu \mathrm{L}$ acetone and shaking the plate for $10 \mathrm{~min}$ at $37^{\circ} \mathrm{C}$ after which absorbance was measured at $405 \mathrm{~nm}$ in each well. The recorded absorbance was plotted against the logarithm of the corresponding concentration in each well to quantify hemozoin inhibition activity ( $\mathrm{IC}_{50}$ values) by nonlinear regression analysis in GraphPad Prism (v. 8.0.2, 2019, GraphPad Software, San Diego, CA 92108, USA).

\subsubsection{UV-Vis DNA Titration Experiment for DNA Binding}

A fixed concentration of calf thymus DNA $(70 \mathrm{ng} / \mu \mathrm{L})$ in a 96-well plate was treated with different concentrations of compound 11b (range: 1-100 $\mu \mathrm{M}$ ) prepared from a 20 $\mathrm{mM}$ stock solution (in DMSO) with milli-Q water and incubated at $37^{\circ} \mathrm{C}$ for $15 \mathrm{~min}$. This was followed by recording the absorbance of the samples in each well from 230-290 nm on a SpectraMax M3 microplate plate reader (Molecular Devices, San Jose, CA, USA). Absorbance of the $100 \mu \mathrm{M}$ compound sample (without DNA) as well as unbound DNA were similarly treated. The binding affinity of the tool compound (11b) was determined by plotting concentration-dependent response curves as spectra showing absorbance over the tested wavelength range. DNA binding affinity was quantified as the binding constant $\left(\mathrm{K}_{\mathrm{b}}\right)$ determined as a ratio of the $y$-intercept to slope of the guest-host reciprocal plot (Equation (1)) depicting the relationship between maximal absorbance (around $260 \mathrm{~nm}$ ) in each well to the corresponding compound concentration.

\subsubsection{Methylene Blue and Hoechst 33342 DNA Binding Assay for Competitive} Intercalation or Minor Groove Binding

Concentrations of compound $\mathbf{1 1 b}(0,50$ and $100 \mu \mathrm{M})$, prepared as described above, were placed with calf thymus DNA $(70 \mathrm{ng} / \mu \mathrm{L})$ in a 96-well plate after which a solution of methylene blue $(1.5 \mu \mathrm{g} / \mathrm{mL})$ or Hoechst 33342 dye $(1.0 \mu \mathrm{g} / \mathrm{mL})$ in distilled water were added to each well. The samples were kept in the dark for $15 \mathrm{~min}$ at ambient temperature and the fluorescence spectra were recorded $\left(\lambda_{\mathrm{ex}}=665 \mathrm{~nm}, \lambda_{\mathrm{em}} 650-750 \mathrm{~nm}\right.$ for methylene blue; $\lambda_{\mathrm{ex}}=350 \mathrm{~nm}, \lambda_{\mathrm{em}}=400-600 \mathrm{~nm}$ for Hoechst 33342) and the results interpreted according to each dye's DNA binding mode.

\section{Conclusions}

In the current study, the hybridisation strategy was employed to assemble bioactive chemical moieties, ferrocene, coumarin and oxazine, into a focused series of ferrocenyl coumarin-1,3-oxazine derivatives with the aim of expanding on the previous work on related ferrocenyl benzoxazines and $\alpha$-aminocresols by investigating the pharmacological effects of annulling coumarin to the phenyl unit of these compounds. Biological evaluation of these coumarin-annulated derivatives on the CQS 3D7 P. falciparum strain and T. $b$. brucei 427 trypomastigotes shows that the introduction of the coumarin unit is tolerated for biological activity of this class of compounds mostly in the low micromolar range, albeit lower potency is also observed. This structural modification proved limiting for anticancer activity against the HCC70 triple-negative breast cancer cell line. To gain insight into the plausible mechanistic action of the compounds, compound $11 \mathrm{~b}$ showing promising potency against both parasitic strains was assessed for potential hemozoin inhibition and DNA interaction and was found to act on both targets, suggesting that this class of compounds likely interacts with these biomolecules to exhibit biological activity similar to the parent benzoxazine and aminocresol counterparts. Overall, the current study sheds more light into the enriched SAR model of ferrocenyl 1,3-benzoxazines and aminocresols and paves the way for further structural optimisation of these compounds to produce better performing analogues as antiparasitic agents for future investigation. 
Supplementary Materials: The following are available online, the NMR spectral data and information pertaining to the HeLa cell evaluation bioassay, such as Figure S1: Results of preliminary cytotoxicity evaluation assay showing percentage viability of HeLa cells plotted in parallel with percentage growth of 3D7 P. falciparum parasites treated with $20 \mu \mathrm{M}$ fixed concentration of the test compounds, can be accessed via the online version of this paper.

Author Contributions: Conceptualization, M.M., A.L.E. and S.D.K.; methodology, M.M., L.M.K.D., A.L.E. and S.D.K.; validation, M.M., A.L.E and S.D.K.; formal analysis, M.M., D.L., T.S., L.M.K.D., A.L.E. and S.D.K.; investigation, M.M., A.I.Z., D.L., T.S. and L.M.K.D.; resources, J.-A.d.1.M., H.C.H., A.L.E., S.D.K.; data curation, M.M., A.L.E. and S.D.K..; validation, M.M. and L.M.K.D.; visualization, M.M.; writing—original draft preparation, M.M.; writing—review and editing, all authors; supervision, A.L.E. and S.D.K.; project administration, S.D.K.; funding acquisition, J.-A.d.1.M., H.C.H., A.L.E. and S.D.K. All authors have read and agreed to the published version of the manuscript.

Funding: This research was funded by the Rhodes University Sandisa Imbewu Grant (S.D.K., H.C.H., J.-A.d.l.M. and A.L.E.), the National Research Foundation of South Africa (M.M., L.M.K.D., T.S., J.-A.d.l.M., H.C.H., A.L.E. and S.D.K.), Thuthuka National Research Foundation (grant no. 107270, S.D.K., 190403426633, J.-A.d.1.M.), The South African Research Chairs Initiative of the Department of Science and Technology and National Research Foundation of South Africa (grant no. 98566, A.L.E.) and National Research Foundation CPRR (grant no. 105829, A.L.E.).

Institutional Review Board Statement: Not applicable.

Informed Consent Statement: Not applicable.

Data Availability Statement: The data provided in this study are available in the article and supplementary material file submitted.

Acknowledgments: The authors acknowledge their respective, current institutions of affiliation: Rhodes University and University of Cape Town (M.M.).

Conflicts of Interest: The authors declare no conflict of interest.

\section{References}

1. Perkins, S.L. Species concepts and malaria parasites: Detecting a cryptic species of Plasmodium. Proc. R. Soc. B 2000, 267, 2345-2350. [CrossRef] [PubMed]

2. World Health Organization. Malaria. Available online: https://www.who.int/health-topics/malaria\#tab=tab_1 (accessed on 26 November 2020).

3. Smith, T.K.; Bringaud, F.; Nolan, D.P.; Figueiredo, L.M. Metabolic reprogramming during the Trypanosoma brucei life cycle. F1000Research 2017, 6. [CrossRef] [PubMed]

4. Medicines for Malaria Venture. The Pathogen Box. Available online: https://www.mmv.org/mmv-open/pathogen-box (accessed on 20 August 2020).

5. Drugs for Neglected Disease Initiative (NDDi). Available online: https://dndi.org/ (accessed on 31 October 2020).

6. Nosten, F.; White, N.J. Artemisinin-based combination treatment of falciparum malaria. Am. J. Trop. Med. Hyg. 2007, 77 (Suppl. 6), 181-192. [CrossRef]

7. World Health Organization. WHO Status Reports on Artemisinin Resistance and ACT Efficacy. Available online: https: //www.who.int/malaria/areas/drug_resistance/updates/en/ (accessed on 26 November 2020).

8. Patra, M.; Gasser, G. The medicinal chemistry of ferrocene and its derivatives. Nat. Rev. Chem. 2017, 1, 1-12. [CrossRef]

9. Singh, A.; Lumb, I.; Mehra, V.; Kumar, V. Ferrocene-appended pharmacophores: An exciting approach for modulating the biological potential of organic scaffolds. Dalton Trans. 2019, 48, 2840-2860. [CrossRef]

10. Xiao, J.; Sun, Z.; Kong, F.; Gao, F. Current scenario of ferrocene-containing hybrids for antimalarial activity. Eur. J. Med. Chem. 2020, 185, 111791. [CrossRef] [PubMed]

11. Abraham, M.H.; Benjelloun-Dakhama, N.; Gola, J.M.; Acree, W.E., Jr.; Cain, W.S.; Cometto-Muniz, J.E. Solvation descriptors for ferrocene, and the estimation of some physicochemical and biochemical properties. New J. Chem. 2000, 24, 825-829. [CrossRef]

12. Astruc, D. Why is ferrocene so exceptional? Eur. J. Inorg. Chem. 2017, 2017, 6-29. [CrossRef]

13. Biot, C.; Glorian, G.; Maciejewski, L.A.; Brocard, J.S.; Domarle, O.; Blampain, G.; Millet, P.; Georges, A.J.; Abessolo, H.; Dive, D. Synthesis and antimalarial activity in vitro and in vivo of a new ferrocene- chloroquine analogue. J. Med. Chem. 1997, 40, 3715-3718. [CrossRef] [PubMed]

14. Top, S.; Tang, J.; Vessières, A.; Carrez, D.; Provot, C.; Jaouen, G. Ferrocenyl hydroxytamoxifen: A prototype for a new range of oestradiol receptor site-directed cytotoxics. Chem. Commun. 1996, 955-956. [CrossRef] 
15. Tan, Y.L.K.; Pigeon, P.; Top, S.; Labbé, E.; Buriez, O.; Hillard, E.A.; Vessières, A.; Amatore, C.; Leong, W.K.; Jaouen, G. Ferrocenyl catechols: Synthesis, oxidation chemistry and anti-proliferative effects on MDA-MB-231 breast cancer cells. Dalton Trans. 2012, 41, 7537-7549. [CrossRef] [PubMed]

16. Jaouen, G.; Vessières, A.; Top, S. Ferrocifen type anti cancer drugs. Chem. Soc. Rev. 2015, 44, 8802-8817. [CrossRef] [PubMed]

17. N'Da, D.D.; Smith, P.J. Synthesis, in vitro antiplasmodial and antiproliferative activities of a series of quinoline-ferrocene hybrids. Med. Chem. Res. 2014, 23, 1214-1224. [CrossRef]

18. Li, Y.; de Kock, C.; Smith, P.J.; Chibale, K.; Smith, G.S. Synthesis and evaluation of a carbosilane congener of ferroquine and its corresponding half-sandwich ruthenium and rhodium complexes for antiplasmodial and $\beta$-hematin inhibition activity. Organometallics 2014, 33, 4345-4348. [CrossRef]

19. Stringer, T.; Wiesner, L.; Smith, G.S. Ferroquine-derived polyamines that target resistant Plasmodium falciparum. Eur. J. Med. Chem. 2019, 179, 78-83. [CrossRef]

20. Minić, A.; Van de Walle, T.; Van Hecke, K.; Combrinck, J.; Smith, P.J.; Chibale, K.; D’hooghe, M. Design and synthesis of novel ferrocene-quinoline conjugates and evaluation of their electrochemical and antiplasmodium properties. Eur. J. Med. Chem. 2020, 187, 111963. [CrossRef]

21. Quirante, J.; Dubar, F.; González, A.; Lopez, C.; Cascante, M.; Cortés, R.; Forfar, I.; Pradines, B.; Biot, C. Ferrocene-indole hybrids for cancer and malaria therapy. J. Organomet. Chem. 2011, 696, 1011-1017. [CrossRef]

22. Radulović, N.S.; Zlatković, D.B.; Mitić, K.V.; Randjelović, P.J.; Stojanović, N.M. Synthesis, spectral characterization, cytotoxicity and enzyme-inhibiting activity of new ferrocene-indole hybrids. Polyhedron 2014, 80, 134-141. [CrossRef]

23. Muenzner, J.K.; Ahmad, A.; Rothemund, M.; Schrüfer, S.; Padhye, S.; Sarkar, F.H.; Schobert, R.; Biersack, B. Ferrocene-substituted 3, 3'-diindolylmethanes with improved anticancer activity. Appl. Organomet. Chem. 2016, 30, 441-445. [CrossRef]

24. Toro, P.; Klahn, A.H.; Pradines, B.; Lahoz, F.; Pascual, A.; Biot, C.; Arancibia, R. Organometallic benzimidazoles: Synthesis, characterization and antimalarial activity. Inorg. Chem. Commun. 2013, 35, 126-129. [CrossRef]

25. Babgi, B.A.; Abdellattif, M.H.; Hussien, M.A.; Eltayeb, N.E. Exploring DNA-Binding and anticancer properties of benzoimidazolylferrocene dye. J. Mol. Struct. 2019, 1198, 126918. [CrossRef]

26. De Lange, C.; Coertzen, D.; Smit, F.J.; Wentzel, J.F.; Wong, H.N.; Birkholtz, L.-M.; Haynes, R.K.; David, D.D. Synthesis, in vitro antimalarial activities and cytotoxicities of amino-artemisinin-ferrocene derivatives. Bioorg. Med. Chem. Lett. 2018, 28, 289-292. [CrossRef] [PubMed]

27. De Lange, C.; Coertzen, D.; Smit, F.J.; Wentzel, J.F.; Wong, H.N.; Birkholtz, L.-M.; Haynes, R.K.; David, D.D. Synthesis, antimalarial activities and cytotoxicities of amino-artemisinin-1, 2-disubstituted ferrocene hybrids. Bioorg. Med. Chem. Lett. 2018, 28, 3161-3163. [CrossRef]

28. Reiter, C.; Fröhlich, T.; Zeino, M.; Marschall, M.; Bahsi, H.; Leidenberger, M.; Friedrich, O.; Kappes, B.; Hampel, F.; Efferth, T. New efficient artemisinin derived agents against human leukemia cells, human cytomegalovirus and Plasmodium falciparum: 2nd generation 1, 2, 4-trioxane-ferrocene hybrids. Eur. J. Med. Chem. 2015, 97, 164-172. [CrossRef]

29. Lacy, A.; O'Kennedy, R. Studies on coumarins and coumarin-related compounds to determine their therapeutic role in the treatment of cancer. Curr. Pharm. Des. 2004, 10, 3797-3811. [CrossRef]

30. Önder, A. Anticancer activity of natural coumarins for biological targets. Stud. Nat. Prod. Chem. 2020, 64, 85-109.

31. Sashidhara, K.V.; Kumar, A.; Dodda, R.P.; Krishna, N.N.; Agarwal, P.; Srivastava, K.; Puri, S. Coumarin-trioxane hybrids: Synthesis and evaluation as a new class of antimalarial scaffolds. Bioorg. Med. Chem. Lett. 2012, 22, 3926-3930. [CrossRef] [PubMed]

32. Hu, X.-L.; Gao, C.; Xu, Z.; Liu, M.-L.; Feng, L.-S.; Zhang, G.-D. Recent development of coumarin derivatives as potential antiplasmodial and antimalarial agents. Curr. Top. Med. Chem. 2018, 18, 114-123. [CrossRef]

33. Pérez-Cruz, F.; Serra, S.; Delogu, G.; Lapier, M.; Maya, J.D.; Olea-Azar, C.; Santana, L.; Uriarte, E. Antitrypanosomal and antioxidant properties of 4-hydroxycoumarins derivatives. Bioorg. Med. Chem. Lett. 2012, 22, 5569-5573. [CrossRef] [PubMed]

34. Gonçalves, G.A.; Cerecetto, H.; Poser, G.; Canto, R.F.S.; Eifler-Lima, V.L. Chagas disease and coumarins: A review of natural and synthetic coumarins as anti-Trypanosoma cruzi agents. Mini-Rev. Med. Chem. 2020. [CrossRef]

35. Gonçalves, G.A.; Spillere, A.R.; das Neves, G.M.; Kagami, L.P.; von Poser, G.L.; Canto, R.F.S.; Eifler-Lima, V.L. Natural and synthetic coumarins as antileishmanial agents: A review. Eur. J. Med. Chem. 2020, 203, 112514. [CrossRef]

36. Mandlik, V.; Patil, S.; Bopanna, R.; Basu, S.; Singh, S. Biological activity of coumarin derivatives as anti-leishmanial agents. PLoS ONE 2016, 11, e0164585. [CrossRef]

37. Keri, R.S.; Sasidhar, B.; Nagaraja, B.M.; Santos, M.A. Recent progress in the drug development of coumarin derivatives as potent antituberculosis agents. Eur. J. Med. Chem. 2015, 100, 257-269. [CrossRef]

38. Hu, Y.-Q.; Xu, Z.; Zhang, S.; Wu, X.; Ding, J.-W.; Lv, Z.-S.; Feng, L.-S. Recent developments of coumarin-containing derivatives and their anti-tubercular activity. Eur. J. Med. Chem. 2017, 136, 122-130. [CrossRef] [PubMed]

39. Mbaba, M.; Mabhula, A.N.; Boel, N.; Edkins, A.L.; Isaacs, M.; Hoppe, H.C.; Khanye, S.D. Ferrocenyl and organic novobiocin derivatives: Synthesis and their in vitro biological activity. J. Inorg. Biochem. 2017, 172, 88-93. [CrossRef] [PubMed]

40. Mbaba, M.; De la Mare, J.-A.; Sterrenberg, J.N.; Kajewole, D.; Maharaj, S.; Edkins, A.L.; Isaacs, M.; Hoppe, H.C.; Khanye, S.D. Novobiocin-ferrocene conjugates possessing anticancer and antiplasmodial activity independent of HSP90 inhibition. J. Biol. Inorg. Chem. 2019, 24, 139-149. [CrossRef] [PubMed] 
41. Biao, L.; Qiuxia, L.; Yuanqing, Z.; Zhaodong, J.; Manyu, Z.; Yan, X.; Maoping, S. Synthesis and Properties of 4-Ferrocenylcarboxybenzene-coumarin Derivatives. Chin. J. Org. Chem. 2017, 37, 2008-2014.

42. Wei, J.-N.; Jia, Z.-D.; Zhou, Y.-Q.; Chen, P.-H.; Li, B.; Zhang, N.; Hao, X.-Q.; Xu, Y.; Zhang, B. Synthesis, characterization and antitumor activity of novel ferrocene-coumarin conjugates. J. Organomet. Chem. 2019, 902, 120968. [CrossRef]

43. Li, W.; Wei, T.; Gao, Y.; Xi, K.; Jia, X. Preparation of novel benzoxazine monomers containing ferrocene moiety and properties of polybenzoxazines. Polymer 2012, 53, 1236-1244. [CrossRef]

44. Li, W.; Chu, J.; Heng, L.; Wei, T.; Gu, J.; Xi, K.; Jia, X. A novel thermal-resistant copolymer from polysiloxane-based polybenzoxazine precursor and ferrocene-based benzoxazine monomer. Polymer 2013, 54, 4909-4922. [CrossRef]

45. Kiskan, B. Adapting benzoxazine chemistry for unconventional applications. React. Funct. Polym. 2018, 129, 76-88. [CrossRef]

46. Mbaba, M.; Dingle, L.M.; Cash, D.; de la Mare, J.-A.; Laming, D.; Taylor, D.; Hoppe, H.C.; Edkins, A.L.; Khanye, S.D. Repurposing a polymer precursor: Synthesis and in vitro medicinal potential of ferrocenyl 1, 3-benzoxazine derivatives. Eur. J. Med. Chem. 2020, 187, 111924. [CrossRef] [PubMed]

47. Mbaba, M.; Dingle, L.M.; Swart, T.; Cash, D.; Laming, D.; de la Mare, J.A.; Taylor, D.; Hoppe, H.C.; Biot, C.; Edkins, A.L. The in vitro antiplasmodial and antiproliferative activity of new ferrocene-based $\alpha$-aminocresols targeting hemozoin inhibition and DNA interaction. ChemBioChem 2020, 21, 2643-2658. [CrossRef] [PubMed]

48. Eckstein, Z.; Urbański, T. 1, 3-Oxazine Derivatives. In Advances in Heterocyclic Chemistry; Elsevier: Amsterdam, The Netherlands, 1979; Volume 23, pp. 1-53.

49. Urbański, T.; Gürne, D.; Šlopek, S.; Mordarska, H.; Mordarski, M. Anti-neoplastic activity of tetrahydro-1, 3-oxazine derivatives. Nature 1960, 187, 426-427. [CrossRef]

50. Lohar, T.; Mane, A.; Kamat, S.; Salunkhe, R. A versatile water-stable fluorine containing organometallic lewis acid used in green synthesis of 1, 3-oxazine scaffolds at room temperature. Polycycl. Aromat. Compd. 2018, 1-13. [CrossRef]

51. Milevskii, B.; Chibisova, T.; Solov'eva, N.; Anisimova, O.; Lebedev, V.; Ivanov, I.; Traven, V. Synthesis and structure of Schiff bases derived from 3-formyl-4-hydroxycoumarin and diamines. Chem. Heterocycl. Compd. 2013, 48, 1781-1792. [CrossRef]

52. Li, J.-S.; Fu, D.-M.; Xue, Y.; Li, Z.-W.; Li, D.-L.; Da, Y.-D.; Yang, F.; Zhang, L.; Lu, C.-H.; Li, G. One-step synthesis of furocoumarins via oxidative annulation of 4-hydroxycoumarins with DDQ. Tetrahedron 2015, 71, 2748-2752. [CrossRef]

53. Jung, J.-C.; Jung, Y.-J.; Park, O.-S. A convenient one-pot synthesis of 4-hydroxycoumarin, 4-hydroxythiocoumarin, and 4hydroxyquinolin-2 (1 H)-one. Synth. Commun. 2001, 31, 1195-1200. [CrossRef]

54. Rad-Moghadam, K.; Mohseni, M. A route to the synthesis of novel coumarins. Monatsh. Chem. 2004, 135, 817-821. [CrossRef]

55. Abdel-Magid, A.F.; Carson, K.G.; Harris, B.D.; Maryanoff, C.A.; Shah, R.D. Reductive amination of aldehydes and ketones with sodium triacetoxyborohydride. studies on direct and indirect reductive amination procedures1. J. Org. Chem. 1996, 61, 3849-3862. [CrossRef]

56. Traven, V.F.; Negrebetsky, V.V.; Vorobjeva, L.I.; Carberry, E.A. Keto-enol tautomerism, NMR spectra, and H-D exchange of 4-hydroxycoumarins. Can. J. Chem. 1997, 75, 377-383. [CrossRef]

57. Ribeiro, M.; Francisco, W.; Rodrigues-Oliveira, A.F.; Correra, T.C. Benzoxazine formation mechanism evaluation by direct observation of reaction intermediates. J. Phys. Chem. A 2019, 123, 8179-8187. [CrossRef] [PubMed]

58. D'Addona, D.; Bochet, C.G. Preparation of carbamates from amines and alcohols under mild conditions. Tetrahedron Lett. 2001, 42, 5227-5229. [CrossRef]

59. Gemma, S.; Camodeca, C.; Brindisi, M.; Brogi, S.; Kukreja, G.; Kunjir, S.; Gabellieri, E.; Lucantoni, L.; Habluetzel, A.; Taramelli, D. Mimicking the intramolecular hydrogen bond: Synthesis, biological evaluation, and molecular modeling of benzoxazines and quinazolines as potential antimalarial agents. J. Med. Chem. 2012, 55, 10387-10404. [CrossRef] [PubMed]

60. Ncokazi, K.K.; Egan, T.J. A colorimetric high-throughput $\beta$-hematin inhibition screening assay for use in the search for antimalarial compounds. Anal. Biochem. 2005, 338, 306-319. [CrossRef]

61. Lu, W.-J.; Wicht, K.J.; Wang, L.; Imai, K.; Mei, Z.-W.; Kaiser, M.; El Sayed, I.E.T.; Egan, T.J.; Inokuchi, T. Synthesis and antimalarial testing of neocryptolepine analogues: Addition of ester function in SAR study of 2, 11-disubstituted indolo [2, 3-b] quinolines. Eur. J. Med. Chem. 2013, 64, 498-511. [CrossRef] [PubMed]

62. Sirajuddin, M.; Ali, S.; Badshah, A. Drug-DNA interactions and their study by UV-Visible, fluorescence spectroscopies and cyclic voltametry. J. Photochem. Photobiol. B 2013, 124, 1-19. [CrossRef]

63. Saito, S.T.; Silva, G.; Pungartnik, C.; Brendel, M. Study of DNA-emodin interaction by FTIR and UV-vis spectroscopy. J. Photochem. Photobiol. B 2012, 111, 59-63. [CrossRef] [PubMed]

64. Shahabadi, N.; Hadidi, S. Spectroscopic studies on the interaction of calf thymus DNA with the drug levetiracetam. Spectrochim. Acta A 2012, 96, 278-283. [CrossRef]

65. Mbaba, M. Repurposing a Polymer Precursor Scaffold for Medicinal Application: Synthesis, Characterization and Biological Evaluation of Ferrocenyl 1,3-Benzoxazine Derivatives as Potential Antiprotozoal and Anticancer Agents. Ph.D. Thesis, Rhodes University, Makhanda, South Africa, 2019.

66. Vardevanyan, P.; Antonyan, A.; Parsadanyan, M.; Shahinyan, M.; Hambardzumyan, L. Mechanisms for binding between methylene blue and DNA. J. Appl. Spectrosc. 2013, 80, 595-599. [CrossRef]

67. Sandhu, L.C.; Warters, R.L.; Dethlefsen, L.A. Fluorescence studies of Hoechst 33342 with supercoiled and relaxed plasmid pBR322 DNA. Cytometry A 1985, 6, 191-194. [CrossRef] [PubMed] 
68. Bucevičius, J.; Lukinavičius, G.; Gerasimaitè, R. The use of hoechst dyes for DNA staining and beyond. Chemosensors 2018, 6, 18. [CrossRef]

69. Furniss, B.S.; Hannaford, A.J.; Smith, P.W.G.; Tatchell, A.R. Vogel's Text Book of Practical Organic Chemistry, 5th ed.; Longmann Scientific \& Technical: New York, NY, USA, 1989.

70. Makler, M.T.; Hinrichs, D.J. Measurement of the lactate dehydrogenase activity of Plasmodium falciparum as an assessment of parasitemia. Am. J. Trop. Med. Hyg. 1993, 48, 205-210. [CrossRef] [PubMed] 